Contract Program or Project Title:

Subject of this Documentation:

Type of Document:

Authors:
Heavy-Section Steel Irradiation Program

Preliminary Results from Charpy Impact Testing of Irradiated JPDR Weld Metal and Commissioning of a Facility for Machining of Irradiated Materials

S. K. Iskander, J. T. Hutton, L. E. Creech, R. K. Nanstad, E. T. Manneschmidt, T. M. Rosseel, and P. S. Bishop

September 1999

C. J. Fairbanks, 301-415-6719

Division of Engineering Technology

Office of Nuclear Regulatory Research

NRC Office or Division:

Prepared for the U.S. Nuclear Regulatory Commission Office of Nuclear Regulatory Research Under Interagency Agreement DOE 1886-N695-3W

NRC JCN W6953

Prepared by the OAK RIDGE NATIONAL LABORATORY

Oak Ridge, TN 37831-6151

Managed by LOCKHEED MARTIN ENERGY RESEARCH CORPORATION for the U.S. Department of Energy Under Contract No. DE-AC05-96OR22464 
Preliminary Results from Charpy Impact Testing of Irradiated JPDR Weld Metal and Commissioning of a Facility for Machining of Irradiated Materials

S. K. Iskander, J. T. Hutton, L. E. Creech, R. K. Nanstad, E. T. Manneschmidt, T. M. Rosseel, and P. S. Bishop

Date Published - September 1999

\author{
Prepared for the \\ U.S. Nuclear Regulatory Commission \\ Office of Nuclear Regulatory Research \\ Under Interagency Agreement DOE 1886-N695-3W
}

NRC JCN W6953

Prepared by the

OAK RIDGE NATIONAL LABORATORY

Oak Ridge, TN 37831-6151

Managed by

LOCKHEED MARTIN ENERGY RESEARCH CORPORATION

for the

U.S. Department of Energy

Under Contract No. DE-AC05-96OR22464 


\section{CONTENTS}

List of Tables $\ldots \ldots \ldots \ldots \ldots \ldots \ldots \ldots \ldots \ldots \ldots \ldots \ldots \ldots \ldots \ldots \ldots$

List of Figures $\ldots \ldots \ldots \ldots \ldots \ldots \ldots \ldots \ldots \ldots \ldots \ldots \ldots \ldots \ldots \ldots \ldots$ vii

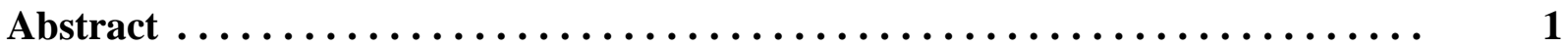

1. Introduction $\ldots \ldots \ldots \ldots \ldots \ldots \ldots \ldots \ldots \ldots \ldots \ldots \ldots \ldots \ldots \ldots \ldots \ldots$

2. Trepans Shipped to ORNL $\ldots \ldots \ldots \ldots \ldots \ldots \ldots \ldots \ldots \ldots \ldots \ldots \ldots \ldots$

3. Commissioning of Facilities for Machining of Irradiated Materials $\ldots \ldots \ldots$

4. Sequence of Machining Operations $\ldots \ldots \ldots \ldots \ldots \ldots \ldots \ldots \ldots \ldots \ldots \ldots$

5. Results from Charpy Testing $\ldots \ldots \ldots \ldots \ldots \ldots \ldots \ldots \ldots \ldots \ldots \ldots \ldots \ldots$

6. References $\ldots \ldots \ldots \ldots \ldots \ldots \ldots \ldots \ldots \ldots \ldots \ldots \ldots \ldots \ldots \ldots \ldots \ldots \ldots \ldots$

Appendix A - Excerpt from Reference 1 of the Report .............. A-1

Appendix B - Sample Photographs of Disks Machined from JPDR Trepans

with the Weld Fusion Lines Marked to Indicate Their Locations . . B-1

Appendix C - Sequence of Operations Required to Machine Charpy Specimens

from Irradiated JPDR Trepans $\ldots \ldots \ldots \ldots \ldots \ldots \ldots \ldots \ldots$ C-1 


\section{List of Tables}

Table 1. Data on the Japan Power Demonstration Reactor

Table 2. Chemical analysis of 6- to 7-g particles sampled every $10 \mathrm{~mm}$ (performed by JAERI Analytical Chemistry Laboratory, November 1977)

Table 3. Chemical analysis of samples extracted from several points through wall and mixed (performed by JAERI Analytical Chemistry Laboratory, October 1993)

Table 4. Total number of trepans removed from the JPDR vessel and sent to ORNL

Table 5. Dimensions of disks sawed from remote trepans measured to locate w

Table 6. JAERI Charpy results for welds

Table 7. ORNL experimental results from remote locations

Table 8. ORNL beltline results 
vii

\section{List of Figures}

Fig. 1. Schematic drawing of JPDR pressure vessel.

Fig. 2. JPDR reactor pressure vessel (developed drawing) and location of sampling.

Fig. 3. Position of JPDR trepans transported to ORNL. (a) Remote part block. (b) Corebelt block.

Fig. 4. Schematic drawing of machining facility in remote hot cell.

Fig. 5. Photograph of computer numerically controlled milling machine inside the hot cell.

Fig. 6. Schematic drawing showing relationship of trepans to JPDR pressure vessel weld and cladding.

Fig. 7. Schematic drawing showing centering of Charpy specimens with respect to weld close to inner surface in the T-L orientation (crack runs in welding direction).

Fig. 8. Schematic drawing showing location of weld fusion lines on JPDR trepan.

Fig. 9. Charpy impact energy versus temperature results for JPDR remote welds, both JAERI and ORNL data. Data are fit to a hyperbolic tangent function.

Fig. 10. Charpy impact energy versus temperature results for JPDR beltline welds, both JAERI and ORNL data. Data are fit to a hyperbolic tangent function.

Fig. 11. Charpy impact energy versus temperature mean hyperbolic tangent curves for JPDR remote and beltline welds, both JAERI and ORNL data. 


\title{
Preliminary Results from Charpy Impact Testing of Irradiated JPDR Weld Metal and Commissioning of a Facility for Machining of Irradiated Materials
}

\author{
S. K. Iskander, J. T. Hutton, L. E. Creech, R. K. Nanstad, \\ E. T. Manneschmidt, T. M. Rosseel, and P. S. Bishop
}

\begin{abstract}
Forty two full-size Charpy specimens were machined from eight trepans that originated from the Japan Power Demonstration Reactor (JPDR). They were also successfully tested and the preliminary results are presented in this report. The trends appear to be reasonable with respect to the location of the specimens with regards to whether they originated from the beltine or the core regions of the vessel, and also whether they were from the inside or outside regions of the vessel wall. A short synopsis regarding commissioning of the facility to machine irradiated materials is also provided.
\end{abstract}

\section{Introduction}

The Japan Power Demonstration Reactor (JPDR) was a direct cycle boiling-water reactor which operated from 1963 to 1976. A summary of the operating conditions, history, pressure vessel size, and material is presented in Table 1 [1]. Sixteen irradiated trepans were shipped to Oak Ridge National Laboratory (ORNL) from the Japan Atomic Energy Research Institute (JAERI). Half of these trepans were machined from a location remote from the core and the other half were machined from the beltline region. Half of each set were base metal and the rest were weld metal. This report gives preliminary results of testing full-size Charpy specimens machined from the weld metal and a summary of the commissioning of a facility to machine irradiated materials.

Some useful information was excerpted from the report, Integrity Assessment for JPDR Pressure Vessel [2] and is included as Appendix A. Two items from that excerpt are noted. The first is that the reactor was bought from the United States and was constructed by the General Electric Company, but the reactor pressure vessel was fabricated by a Japanese firm using domestic materials [3]. The second was the discovery of hairline cracks in the cladding, which precipitated the investigation mentioned in the excerpt. A drawing of the JPDR vessel is shown in Fig. 1. 


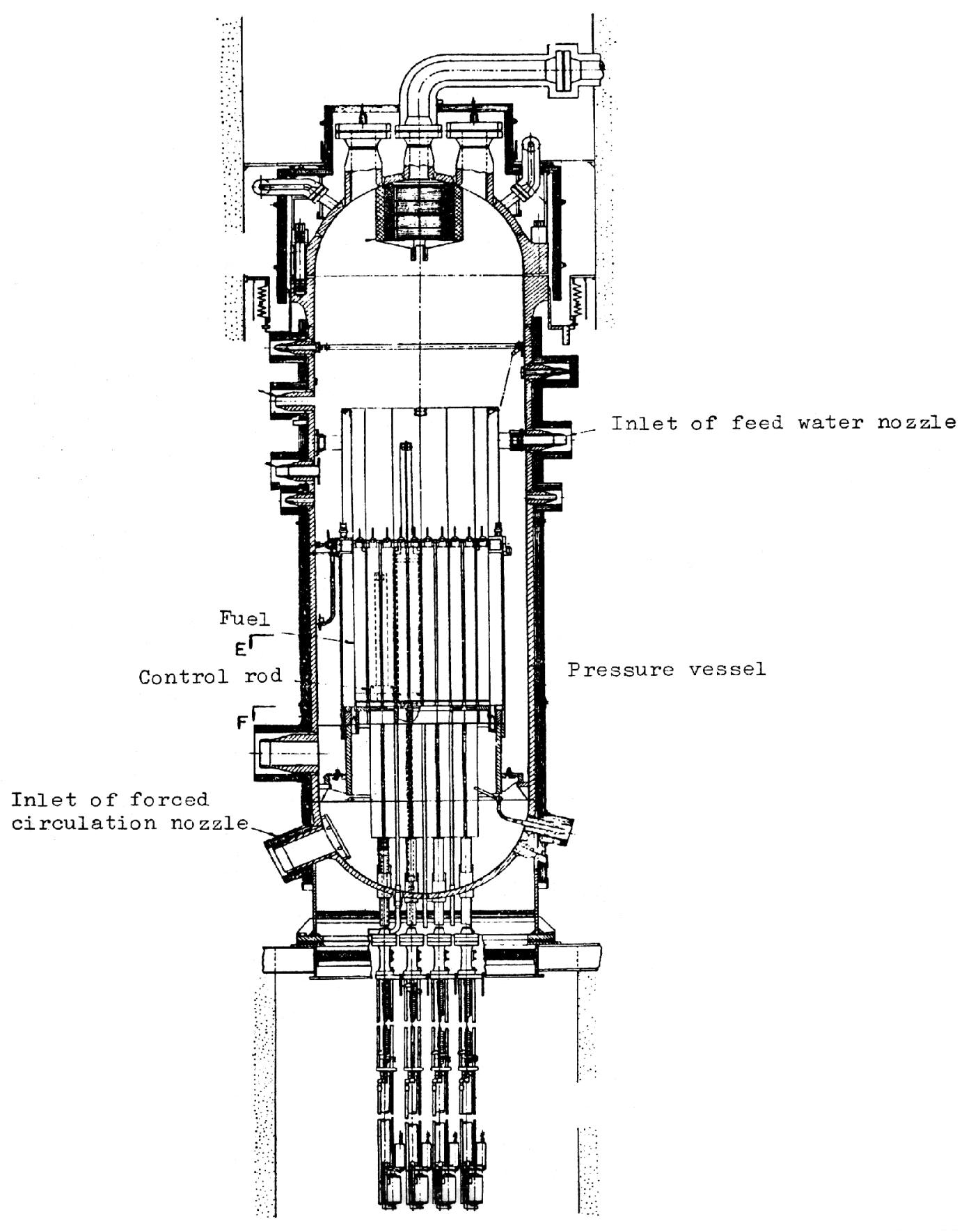

c0000034-1

Fig. 1. Schematic drawing of JPDR pressure vessel. 
Table 1. Data on the Japan Power Demonstration Reactor

\begin{tabular}{|c|c|c|}
\hline Reactor type & \multicolumn{2}{|c|}{ Direct cycle boiling water reactor } \\
\hline Pressure vessel & $\begin{array}{l}\text { Material: } \\
\text { Vessel dimensions: } \\
\text { Wall thickness: }\end{array}$ & $\begin{array}{l}\text { ASTM A302B modified } \\
8 \mathrm{~m} \text { high by } 2 \mathrm{~m} \text { diam ( } 26 \text { by } 6.5 \mathrm{ft}) \\
78 \mathrm{~mm} \text { ( } 3 \text { in.) }\end{array}$ \\
\hline Operating condition & $\begin{array}{l}\text { Temperature: } \\
\text { Pressure: } \\
\text { Output: }\end{array}$ & $\begin{array}{l}277^{\circ} \mathrm{C}\left(530^{\circ} \mathrm{F}\right) \\
6.0 \mathrm{MPa}(870 \mathrm{psi}) \\
45 \mathrm{MW} \text { Thermal, } 12.5 \mathrm{MW}(\mathrm{e})\end{array}$ \\
\hline Operating history & $\begin{array}{l}\text { Operating period: } \\
\text { Total thermal output: } \\
\text { Total operation time: } \\
\text { Maximum fluence: }\end{array}$ & $\begin{array}{l}1963 \text { to } 1976 \\
21,452 \mathrm{MWd} \\
17,097 \mathrm{~h} \\
2 \times 10^{18} \mathrm{n} / \mathrm{cm}^{2}(>1 \mathrm{MeV})\end{array}$ \\
\hline \multicolumn{3}{|c|}{$\begin{array}{l}\text { Source: M. Suzuki, Y. Idei, and K. Onizawa, "Investigation on Irradiation Embrittlement of } \\
\text { Reactor Pressure Vessel Steel Using Decommissioned JPDR," in Technology for Lifetime } \\
\text { Management of Nuclear Power, Proceedings of a Specialists Meeting Organized by the } \\
\text { International Atomic Energy Agency, Tokyo, Japan, November 15-17, } 1994 .\end{array}$} \\
\hline
\end{tabular}

Table 2. Chemical analysis of 6- to 7-g particles sampled every $10 \mathrm{~mm}$ (performed by JAERI Analytical Chemistry Laboratory, November 1977)

\begin{tabular}{|c|c|c|c|c|c|c|}
\hline \multirow{2}{*}{$\begin{array}{c}\text { Specimen } \\
\text { identification }\end{array}$} & \multicolumn{7}{|c|}{$\begin{array}{c}\text { Content } \\
\text { (wt \%) }\end{array}$} \\
\cline { 2 - 7 } & $\mathrm{Si}$ & $\mathrm{Mn}$ & $\mathrm{Mo}$ & $\mathrm{Ni}$ & $\mathrm{Cu}$ & $\mathrm{Cr}$ \\
\hline $927-1^{a}$ & 0.73 & 1.45 & 0.62 & 1.20 & 0.12 & 1.22 \\
$927-2$ & 0.36 & 1.59 & 0.57 & 0.69 & 0.15 & 0.07 \\
$927-3$ & 0.46 & 1.62 & 0.56 & 0.72 & 0.15 & 0.06 \\
$927-4$ & 0.38 & 1.61 & 0.57 & 0.71 & 0.15 & 0.07 \\
$927-5$ & 0.40 & 1.57 & 0.54 & 0.70 & 0.14 & 0.07 \\
$927-6$ & 0.68 & 1.52 & 0.52 & 0.66 & 0.15 & 0.07 \\
$927-7^{b}$ & 0.63 & 1.57 & 0.60 & 0.49 & 0.15 & 0.08 \\
\hline
\end{tabular}


The chemical analysis of the weld was performed by JAERI,* and the variation of the composition through the thickness for one weld is given in Table 2. The effect of cladding on the composition is evident in the results of the analysis of the innermost sample. Samples extracted from several locations and mixed to give an average composition of $\mathrm{P}, \mathrm{Ni}$, and $\mathrm{Cu}$ is given in Table 3 .

\section{Trepans Shipped to ORNL}

Figure 2 shows the locations from which the remote and corebelt blocks of material, each approximately $900 \mathrm{~mm}$ along the circumference and about $800 \mathrm{~mm}$ in the axial direction, were cut from the reactor pressure vessel (RPV) [4]. Figure 3 shows the locations and identifications of the trepans removed from each of these blocks. Table 4 shows the total number of trepans removed and those shipped to ORNL.
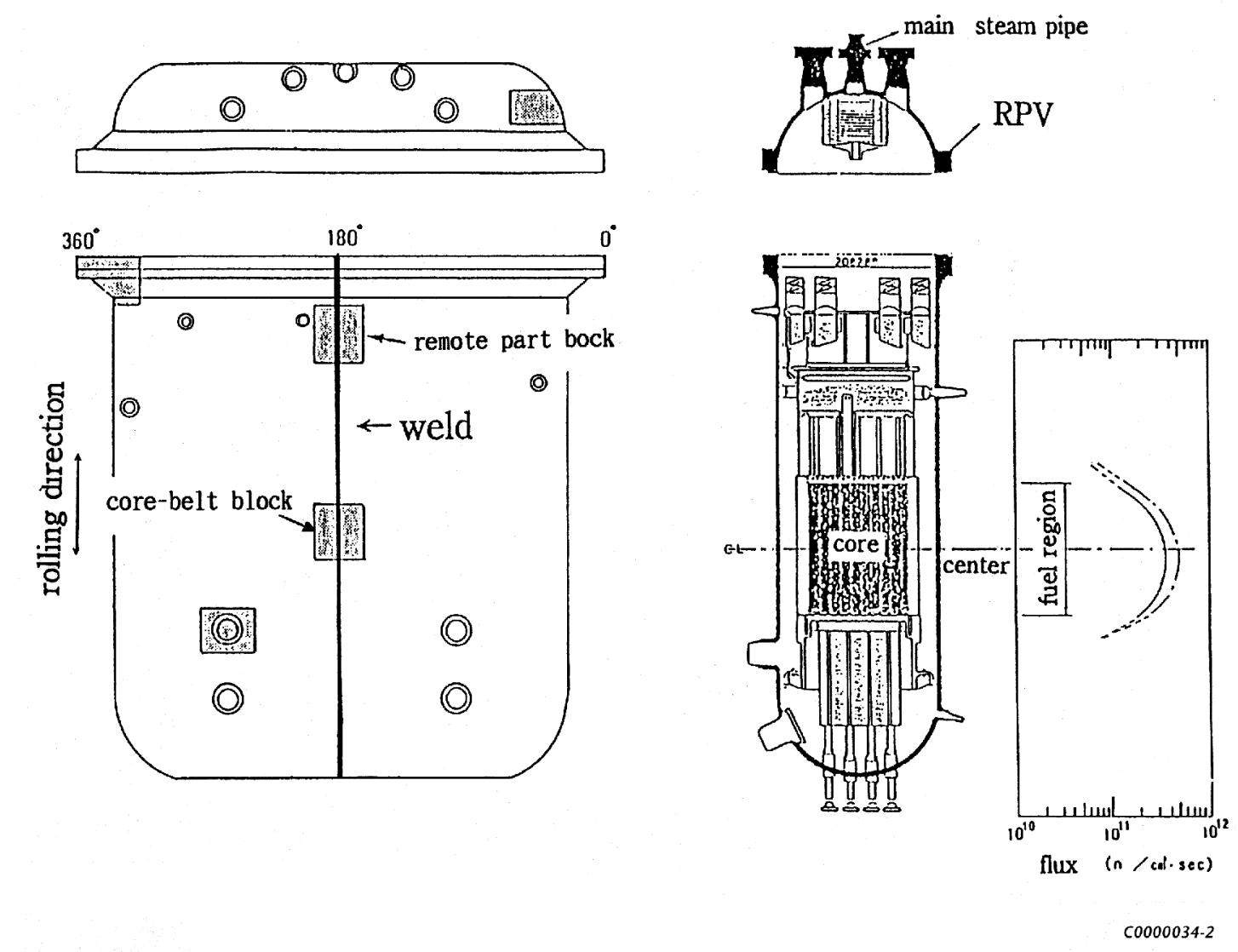

Fig. 2. JPDR reactor pressure vessel (developed drawing) and location of sampling.

*Presentation by M. Suzuki and K. Onizawa of JAERI to the HSSI Program, ORNL, Feb. 24-25, 1998. 
Table 3. Chemical analysis of samples extracted from several points through wall and mixed (performed by JAERI Analytical Chemistry Laboratory, October 1993)

\begin{tabular}{|c|c|c|c|}
\hline \multirow{2}{*}{ Sample origin } & \multicolumn{3}{|c|}{$\begin{array}{c}\text { Composition } \\
\text { (wt \%) }\end{array}$} \\
\cline { 2 - 4 } & $\mathrm{P}$ & $\mathrm{Ni}$ & $\mathrm{Cu}$ \\
\hline From RW1 trepan & 0.025 & 0.59 & 0.14 \\
From RW2 trepan & 0.039 & 0.59 & 0.11 \\
\hline
\end{tabular}

Table 4. Total number of trepans removed from the JPDR vessel and sent to ORNL

\begin{tabular}{|c|c|c|c|c|}
\hline \multirow{2}{*}{ Material } & \multicolumn{2}{|c|}{ RPV beltline } & \multicolumn{2}{c|}{$\begin{array}{c}\text { Remote" from } \\
\text { beltline }\end{array}$} \\
\cline { 2 - 5 } & Total & $\begin{array}{c}\text { Shipped to } \\
\text { ORNL }\end{array}$ & Total & $\begin{array}{c}\text { Shipped to } \\
\text { ORNL }\end{array}$ \\
\hline Base metal & 8 & 4 & 13 & 4 \\
Weld metal & 8 & 4 & 9 & 4 \\
\hline
\end{tabular}

The sixteen trepans $87 \mathrm{~mm}$ in diameter and $78 \mathrm{~mm}$ long were shipped to ORNL from the JAERI. As noted in Table 4, half of these were machined from a location remote from the core, and half from the beltline region. Half of each set were base metal and the other half weld metal. Full-size Charpy specimens were machined from the weld metal and tested. As will be shown later, there is only a V-shaped longitudinal weld in the JPDR vessel. This represented a challenge to remotely position and machine the trepans so that the centerline of the weld is also central to the trepan, otherwise geometric restrictions due to amount of material available would not permit a Charpy specimen containing weld metal to be obtained. As a result, disks that were destined to be used for machining Charpy specimens were first etched to reveal the weld location. Photographs of some of the disks sawed from the trepans taken through the hot cell window are given in Appendix B. Most of the welds were well centered and allowed the machining of Charpy specimens from the disks. This is a remarkable achievement, considering the distance from which this remote operation had to be performed. No specimens have been machined from trepan RW9, because the weld center line was off center with respect to the centerline of the trepan. 


\section{Commissioning of Facilities for Machining of Irradiated Materials}

The commissioning of facilities for machining of irradiated materials involved two separate phases. Two nearly identical Model VMC-100 computer numerically controlled (CNC) milling machines were purchased; one new unit and a "demonstrator" obtained at 50\% of the cost of the new one. The milling unit consists of a nine-tool turret head and a movable table. The turret head supplies the vertical motion to the tools, and will be termed the z-axis motion. The movable table allows left to right motion ( $\mathrm{x}$-axis motion) and front to back (y-axis motion). The maximum working dimensions are $190 \times 100 \times 60 \mathrm{~mm}$ in the $\mathrm{x}-, \mathrm{y}$-, and z-directions, respectively.

One phase of this task was the installation of the demonstrator unit in the Fracture Mechanics Group Laboratory in Building 4500S. It is used for the development of the fixtures and computer programs necessary to operate the mill, and will be referred to as the Prototype Unit. This Prototype Unit proved to be a key element in the performance of this task. It is not an overstatement that this task would have been extremely difficult without it. In fact, even after the completion of code development, code modifications were often necessary to account for differences in the geometry of the trepan. For example, as shown in Fig. 3, one of the trepans, RW7 for example, was gouged during the trepanning operation of the adjacent trepan, necessitating the development of a special machining sequence on the Prototyping Mill. A photograph of the Prototyping Unit is shown in Appendix C (Fig. C.1). 

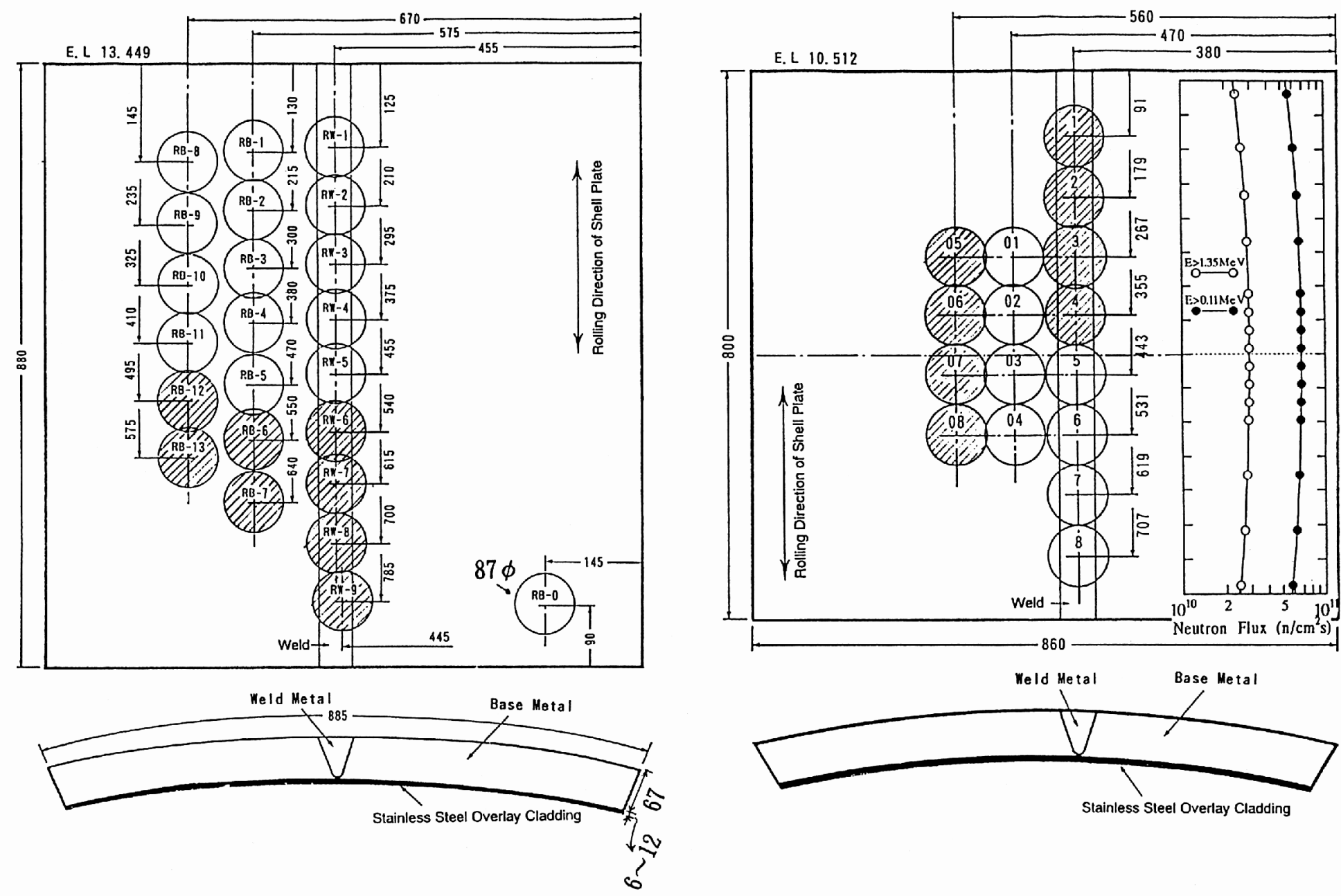

Fig. 3. Position of JPDR trepans transported to ORNL. (a) Remote part block. (b) Corebelt block. 
The other phase was the installation of the new mill and saw in Building 3025E. The drawing in Fig. 4 gives the general layout of the mill and saw in Cell 6 of Building 3025E, and a photograph of the mill through the front window of the hot cell is shown in Fig. 5. The installation of mill and saw required several modifications and extensive reverse engineering. The pneumatic lines needed for both saw and mill had to be introduced through shielded plugs from the operating area behind the cell. To allow refilling of the lubrication reservoir without a cell entry, the reservoir was removed from the rear of the mill and installed in the service area behind the hot cell. The greatest challenge, however, was the control cables for the mill. This mill, as delivered, was configured as two coupled components with 3 feet of several multiple conduit cables connecting the machining unit to a control unit, as shown in Fig. C.1 of Appendix C. In order to allow remote operation, the milling machine was reengineered into three components. Because of radiation shielding requirements, the cables between the control unit and mill had to be increased from 3 to 75 feet. Since the original control unit cannot operate with this length of cabling, it was necessary to split the original control unit into "primary" and "auxiliary" control units as shown in Fig. 4. The primary unit was placed in the operating area in front of the Cell 6 window, and it was then possible to use 75 feet of cable to connect it to the auxiliary unit in the rear of the hot cells that was in close proximity to the milling unit. The machining unit inside Cell 6 is operated by the primary control via the auxiliary unit. The cables between the auxiliary unit and the milling unit are about 15 feet long and penetrate the cell walls through lead shields. There are ten 130-lb lead shield plugs, each with two to four spiral grooves for various size cables, pneumatic lines, and lubrication hoses that are necessary to operate the mill and saw, and whose design and installation was also a challenge. To allow removal for maintenance, it was necessary to link the various components by "quick-connect" Amphenol couplers. A new 1-ton overhead crane was also installed in the cell. 


\section{Sequence of Machining Operations}

Two disks each about $13 \mathrm{~mm}$ thick were sawed from each trepan. The first operation was a saw cut to remove the cladding and heat affected zone (HAZ) on each trepan. Since the cladding is as thick as $12 \mathrm{~mm}$ on some of the trepans, and allowing for $3 \mathrm{~mm}$ of heat-affected zone, the inner surface of the disk cannot be closer than about $15 \mathrm{~mm}$ from the inner surface of the vessel. These disks and the specimens machined from them are referred to as "inner" or "inside" ones. The

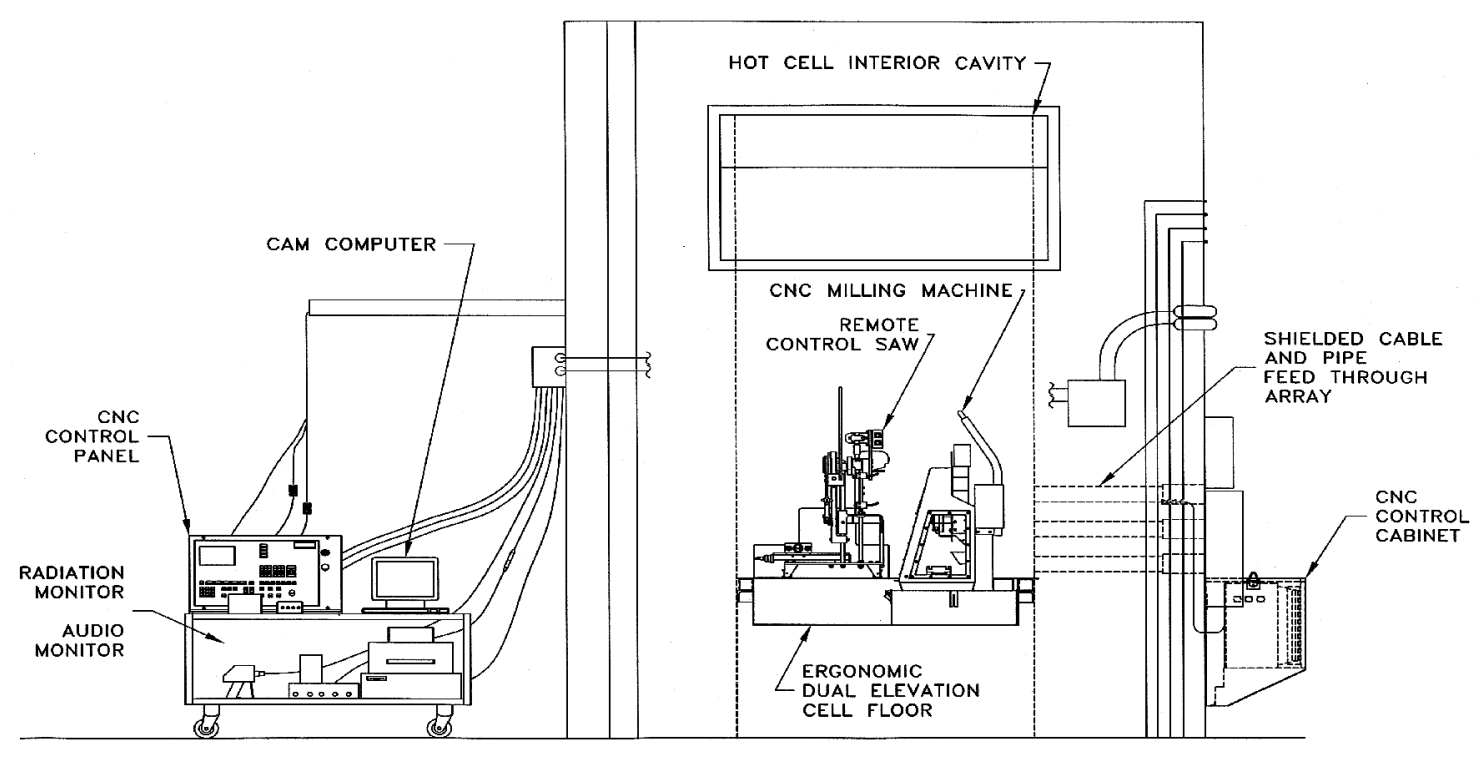

Fig. 4. Schematic drawing of machining facility in remote hot cell.

c0000034-4

Fig. 4. Schematic drawing of machining facility in remote hot cell.

second disk was machined as close as possible to the outside surface of the vessel. Here also, about $6 \mathrm{~mm}$ were removed from the back face of the trepan to remove the thickness equivalent to a last weld bead. Visual examination of the surfaces of the trepans that were on the outside of the vessel indicated that the last weld passes were higher than the outside surface and that they were ground to present a smooth surface. Thus, there was no evidence of the exact weld location. 


\section{Irradiated Pressure Vessel Steels can be Machined into Small Test Specimens with a Remotely Operable Guillotine Saw and Computer Numerically Controlled (CNC) Milling Machine}

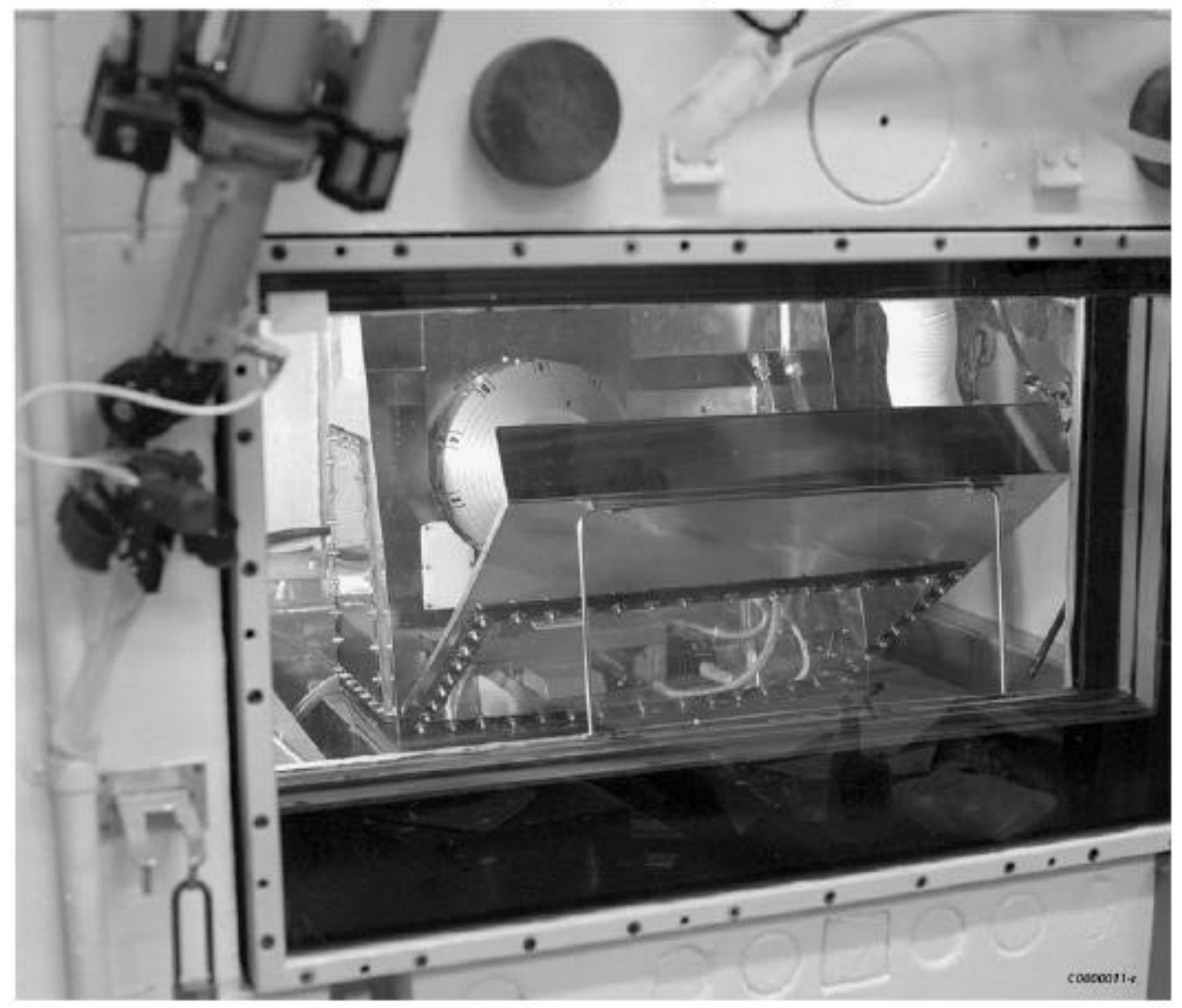

Fig. 5. Photograph of computer numerically controlled milling machine inside the hot cell.

However, it was assumed that no "temper bead" was added in order to ensure that all weld passes were subjected to the same tempering affect of the subsequent bead. The surface of "outer" disks used for machining Charpy specimens are approximately $6 \mathrm{~mm}$ from the outside surface of the vessel.

Figure 6 is a schematic of a radial section through the vessel wall and Fig. 7 shows the layout of the T-L orientation of the Charpy specimens in the cross section of the trepan. It is noted that due to dimensional restrictions and an allowance of about 4-mm machining kerf, three Charpy 


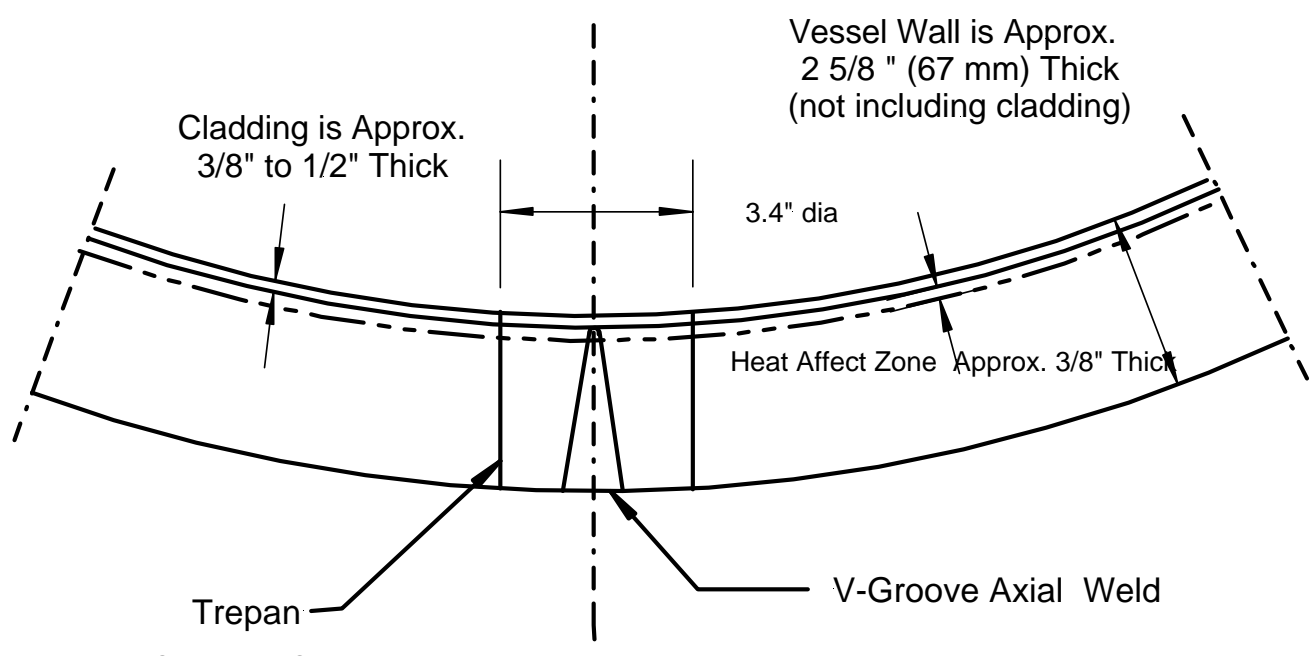

file: Vessel Schematic.SKF

Fig. 6. Schematic drawing showing relationship of trepans to JPDR pressure vessel weld and cladding.

specimens could be obtained from each disk. The tolerance for eccentricity of the weld with respect to the center of the disk is about $3 \mathrm{~mm}$.

A special fixture for remote cutting was designed guided by the following considerations:

1. The circular disks are machined from the trepan cylinders on a guillotine saw, then transferred to the mill.

2. Only one fixture is to be used for the complete machining sequence of the Charpy specimens from the disks, to eliminate the significant amount of time required to remotely remove and reattach another fixture using hot cell manipulators.

3. The limited working dimensions of the mill must be observed. This space is about $190 \mathrm{~mm}$ long, $40 \mathrm{~mm}$ deep and $60 \mathrm{~mm}$ high.

4. Since three stations are required to complete a Charpy specimen, it is necessary to move the disk from one "station" to another to complete the machining. Thus, in the first station, location guide holes, whose purpose is to locate the disk accurately in the second station, are drilled and reamed.

5. In the second station, the Charpy specimen blanks are parted from the disk.

6. Machining the V-notch of the Charpy is completed in a third station. 


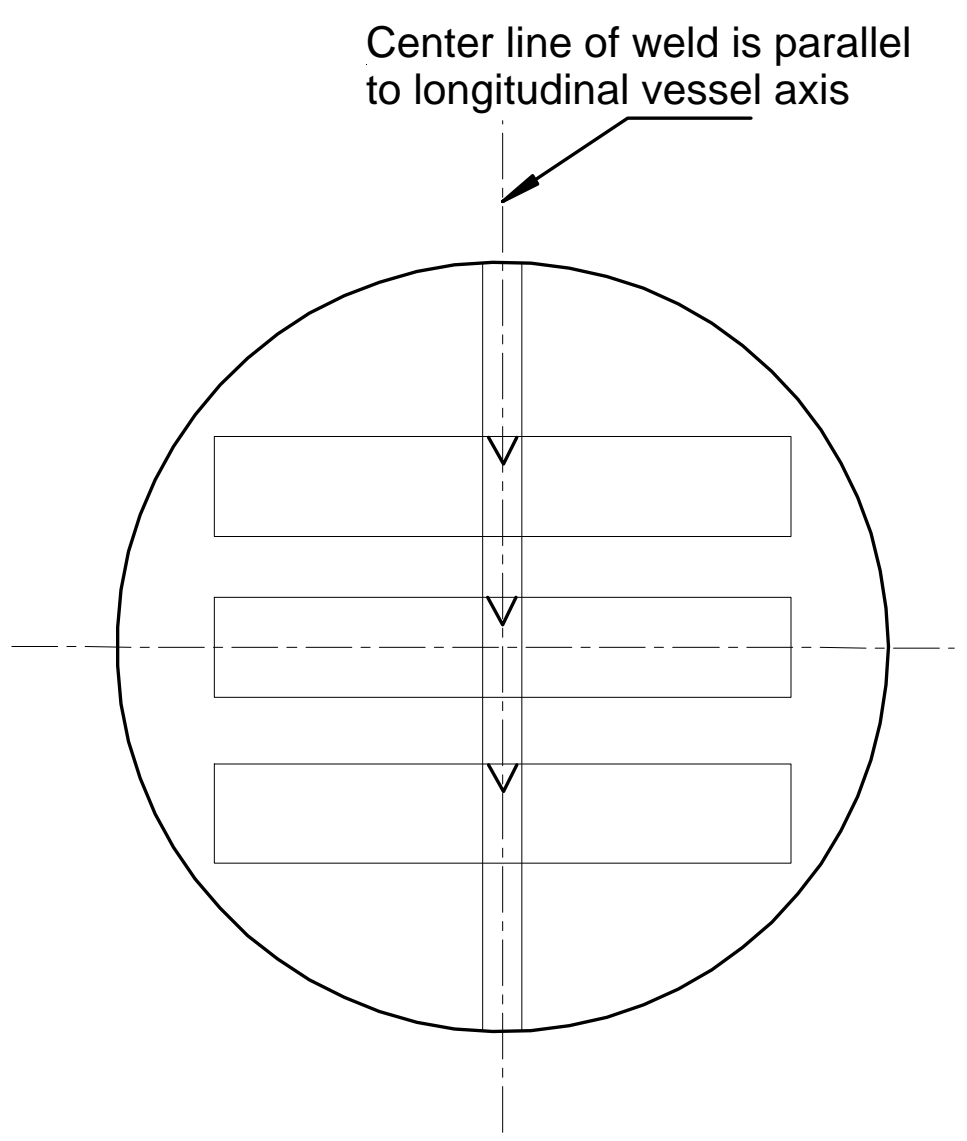

Fig. 7. Schematic drawing showing centering of Charpy specimens with respect to weld close to inner surface in the T-L orientation (crack runs in welding direction). 
Although details of the machining of Charpy specimens from a disk are given in Appendix $\mathrm{C}$, a brief summary is provided here. After the two disks are sawed from each trepan, each disk is clamped in the first "station" of the specially designed fixture. Fresh surfaces are milled and etched to reveal the location of the weld, and the fusion line is marked. A schematic drawing of the fusion zones on a trepan is shown in Fig. 8, and typical dimensions to the weld fusion line as determined by etching are given in Table 5. As mentioned previously, except for Remote Weld trepan RW9, most welds were well centered with respect to the center of the trepan cross section.

Table 5. Dimensions of disks sawed from remote trepans measured to locate weld

\begin{tabular}{|c|c|c|c|c|c|c|c|c|c|c|}
\hline \multirow{2}{*}{ Trepan } & \multicolumn{2}{|c|}{$\mathrm{A}$} & \multicolumn{2}{|c|}{ B } & \multicolumn{2}{|c|}{$\mathrm{C}$} & \multicolumn{2}{|c|}{$\mathrm{W}$} & \multicolumn{2}{|c|}{ Thickness } \\
\hline & $\mathrm{mm}$ & in. & $\mathrm{mm}$ & in. & $\mathrm{mm}$ & in. & $\mathrm{mm}$ & in. & $\mathrm{mm}$ & in. \\
\hline \multicolumn{11}{|c|}{ Inner disks } \\
\hline RW8 & 30.9 & 1.22 & 22.6 & 0.89 & 33.0 & 1.30 & 86.6 & 3.41 & 13.0 & 0.51 \\
\hline RW9 & 19.1 & 0.75 & 19.4 & 0.77 & 48.3 & 1.90 & 86.6 & 3.41 & 11.4 & 0.45 \\
\hline \multicolumn{11}{|c|}{ Outer disks } \\
\hline RW8 & 22.9 & 0.90 & 36.3 & 1.43 & 25.7 & 1.01 & 86.4 & 3.40 & 13.0 & 0.51 \\
\hline RW9 & 8.9 & 0.35 & 38.6 & 1.52 & 38.6 & 1.52 & 86.4 & 3.40 & 14.0 & 0.55 \\
\hline
\end{tabular}




\section{4}

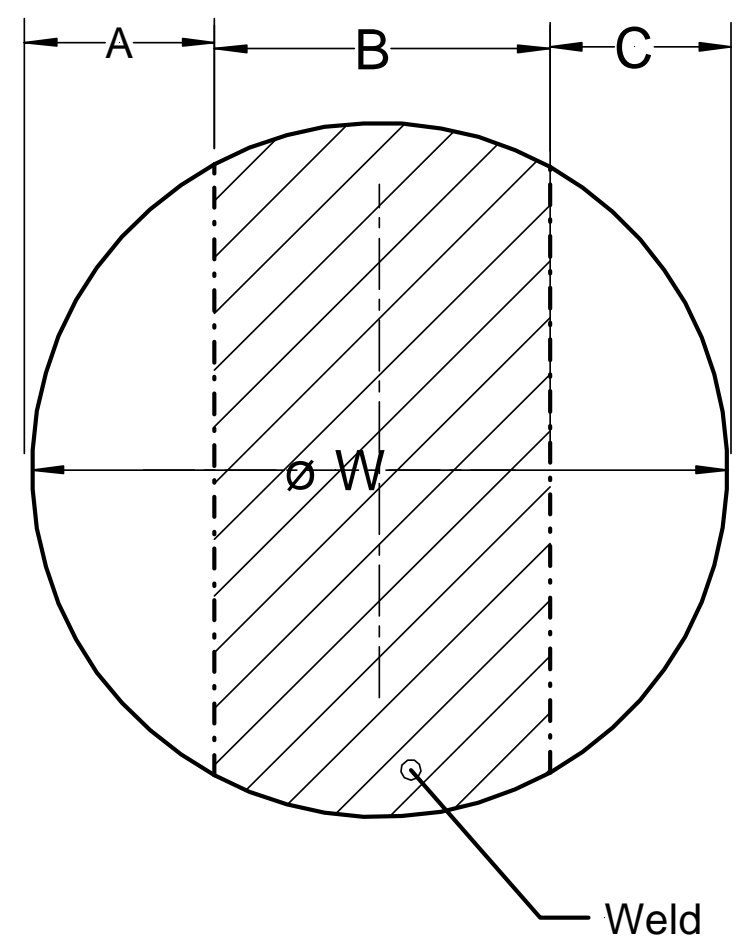

Fig. 8. Schmatic drawing showing

location of weld fusion lines on JPDR trepan.

As mentioned previously, the computer program to perform the above sequence of operations was developed on the Prototyping Unit. The development of the operational sequences was judged to be complete when the machined Charpy specimens conformed to the specifications given in the Standard Test Methods for Notched Bar Impact Testing of Metallic Materials (ASTM E 23-93a). As a control, unirradiated specimens are periodically machined and inspected to ensure that the dimensions of the specimens machined in the hot cell meet the required specifications.

\section{Results from Charpy Testing}

In this report, the results obtained will be presented, but analysis of the data will be deferred until discussions with JAERI are completed. The results of Charpy testing as provided by JAERI are given in Table 6 for specimens machined from the remote and beltline regions of the JPDR. Note that those for the beltline regions of the JPDR are from the so-called second row of specimens which presumably is somewhat further from the inside surface of the vessel.

The results of Charpy tests by ORNL are given in Tables 7 and 8 and plotted together with the JAERI results in Figs. 9 and 10 for the remote and beltline regions, respectively. The trends are 


\section{5}

Table 6. JAERI Charpy results for welds

\begin{tabular}{|l|c|c|c|c|}
\hline Trepan & $\begin{array}{c}\text { Temperature } \\
\left({ }^{\circ} \mathrm{C}\right)\end{array}$ & $\begin{array}{c}\text { Energy } \\
(\mathrm{J})\end{array}$ & $\begin{array}{c}\text { Shear } \\
(\%)\end{array}$ & $\begin{array}{c}\text { Expansion } \\
(\mathrm{mm})\end{array}$ \\
\hline \multicolumn{5}{|c|}{ Remote inside location } \\
\hline RW5 & -75 & 8.35 & 15 & 0.275 \\
RW6 & -60 & 29.2 & 20 & 0.551 \\
RW4 & -50 & 42.12 & 30 & 0.814 \\
RW10 & -50 & 46.24 & 35 & 0.915 \\
RW9 & -45 & 47.54 & 50 & 0.88 \\
RW3 & -30 & 57.59 & 35 & 1.024 \\
RW2 & -10 & 86.26 & 80 & 1.496 \\
RW1 & 15 & 107.09 & 80 & 1.838 \\
RW7 & 50 & 139.37 & 100 & 2.245 \\
RW8 & 50 & 146.69 & 100 & 2.438 \\
\hline \multicolumn{5}{|c|}{ Beltline second row location } \\
\hline W9 & -75 & 22.36 & 5 & 0.439 \\
W6 & -50 & 23.51 & 5 & 0.429 \\
W5 & -30 & 38.32 & 20 & 0.737 \\
W8 & -25 & 41.63 & 30 & 0.806 \\
W4 & -20 & 47.28 & 35 & 0.845 \\
W7 & -10 & 44.44 & 30 & 0.797 \\
W1 & 14.3 & 80.56 & 60 & 1.456 \\
W2 & 50 & 105.92 & 85 & 1.875 \\
W10 & 80 & 108.86 & 85 & 1.887 \\
W3 & 80 & 133.51 & 100 & 2.395 \\
\hline
\end{tabular}


Table 7. ORNL experimental results from remote locations

\begin{tabular}{|c|c|c|c|c|c|c|}
\hline \multirow{2}{*}{ Trepan } & \multirow{2}{*}{$\begin{array}{c}\text { Temperature } \\
\left({ }^{\circ} \mathrm{C}\right)\end{array}$} & \multicolumn{2}{|c|}{ Energy } & \multirow{2}{*}{$\begin{array}{l}\text { Shear } \\
(\%)\end{array}$} & \multicolumn{2}{|c|}{ Expansion } \\
\hline & & (J) & (ft-lb) & & $(\mathrm{mm})$ & (in.) \\
\hline \multicolumn{7}{|c|}{ Inside layer } \\
\hline RW7F3 & -50 & 21.3 & 15.7 & 5 & 0.384 & 0.0151 \\
\hline RW7F1 & 0 & 72.8 & 53.7 & 45 & 1.115 & 0.0439 \\
\hline FW8F1 & -25 & 62.9 & 46.4 & 30 & 1.019 & 0.0401 \\
\hline RW6F2 & -40 & 40.1 & 29.6 & 10 & 0.638 & 0.0251 \\
\hline RW7F2 & -40 & 26.4 & 19.5 & 10 & 0.389 & 0.0153 \\
\hline RW6F1 & -50 & 13.8 & 10.2 & 10 & 0.178 & 0.0070 \\
\hline RW6F3 & 50 & 92.6 & 68.3 & 80 & 1.504 & 0.0592 \\
\hline RW8F3 & 50 & 94.0 & 69.3 & 80 & 1.458 & 0.0574 \\
\hline RW8F2 & 80 & 113.1 & 83.4 & 100 & 1.699 & 0.0669 \\
\hline \multicolumn{7}{|c|}{ Outside layer } \\
\hline RW7B3 & -50 & 56.4 & 41.6 & 5 & 0.945 & 0.0372 \\
\hline RW7B2 & -40 & 44.7 & 33.0 & 10 & 0.757 & 0.0298 \\
\hline RW7B1 & -25 & 57.6 & 42.5 & 45 & 0.914 & 0.0360 \\
\hline RW6B2 & -25 & 50.8 & 37.5 & 25 & 0.886 & 0.0349 \\
\hline RW6B1 & 0 & 78.4 & 57.8 & 70 & 1.313 & 0.0517 \\
\hline RW8B2 & 80 & 96.5 & 71.2 & 100 & 1.478 & 0.0582 \\
\hline RW8B1 & 80 & 102.2 & 75.4 & 100 & 1.359 & 0.0535 \\
\hline RW6B3 & 25 & 98.0 & 72.3 & 100 & 1.445 & 0.0569 \\
\hline RW8B3 & 25 & 93.4 & 68.9 & 95 & 1.458 & 0.0574 \\
\hline
\end{tabular}


Table 8. ORNL beltline results

\begin{tabular}{|c|c|c|c|c|c|c|}
\hline \multirow{2}{*}{ Trepan } & \multirow{2}{*}{$\begin{array}{c}\text { Temperature } \\
\left({ }^{\circ} \mathrm{C}\right)\end{array}$} & \multicolumn{2}{|c|}{ Energy } & \multirow{2}{*}{$\begin{array}{l}\text { Shear } \\
(\%)\end{array}$} & \multicolumn{2}{|c|}{ Expansion } \\
\hline & & (J) & (ft-lb) & & $(\mathrm{mm})$ & (in.) \\
\hline \multicolumn{7}{|c|}{ Inside } \\
\hline $3 \mathrm{~F} 3$ & -25 & 14.1 & 10.4 & 5 & 0.193 & 0.0076 \\
\hline $2 \mathrm{~F} 3$ & -10 & 29.0 & 21.4 & 10 & 0.442 & 0.0174 \\
\hline $2 \mathrm{~F} 1$ & -10 & 30.1 & 22.2 & 15 & 0.574 & 0.0226 \\
\hline $1 \mathrm{~F} 2$ & 0 & 16.1 & 11.9 & 30 & 0.330 & 0.0130 \\
\hline $2 \mathrm{~F} 2$ & 0 & 35.4 & 26.1 & 20 & 0.584 & 0.0230 \\
\hline 3F1 & 10 & 58.2 & 42.9 & 50 & 0.803 & 0.0316 \\
\hline $3 \mathrm{~F} 2$ & 25 & 52.2 & 38.5 & 45 & 0.841 & 0.0331 \\
\hline 1F1 & 25 & 63.7 & 47.0 & 40 & 1.095 & 0.0431 \\
\hline $1 \mathrm{~F} 1$ & 80 & 86.6 & 63.9 & 80 & 1.425 & 0.0561 \\
\hline 4F1 & 80 & 86.8 & 64.0 & 70 & 1.389 & 0.0547 \\
\hline $4 \mathrm{~F} 2$ & 110 & 107.1 & 79.0 & 100 & 1.864 & 0.0734 \\
\hline $4 \mathrm{~F} 3$ & 110 & 113.6 & 83.8 & 100 & 1.859 & 0.0732 \\
\hline \multicolumn{7}{|c|}{ Outside } \\
\hline 3B1 & -50 & 7.7 & 5.7 & 0 & 0.188 & 0.0074 \\
\hline 2B2 & -40 & 19.0 & 14.0 & 10 & 0.300 & 0.0118 \\
\hline 2B1 & -10 & 27.9 & 20.6 & 30 & 0.521 & 0.0205 \\
\hline 2B3 & -10 & 44.7 & 33.0 & 25 & 0.775 & 0.0305 \\
\hline 3B3 & 0 & 51.5 & 38.0 & 30 & 0.899 & 0.0354 \\
\hline 1B3 & 0 & 54.5 & 40.2 & 30 & 0.940 & 0.0370 \\
\hline 4B2 & 25 & 61.4 & 45.3 & 35 & 1.062 & 0.0418 \\
\hline 3B2 & 25 & 76.1 & 56.1 & 60 & 1.288 & 0.0507 \\
\hline $4 \mathrm{~B} 1$ & 50 & 85.4 & 63.0 & 50 & 1.328 & 0.0523 \\
\hline $4 \mathrm{~B} 3$ & 80 & 95.9 & 70.7 & 90 & 1.735 & 0.0683 \\
\hline 1B2 & 100 & 102.4 & 75.5 & 100 & 2.014 & 0.0793 \\
\hline 1B1 & 100 & 110.0 & 81.1 & 95 & 1.808 & 0.0712 \\
\hline
\end{tabular}


reasonable; namely, the curves for the outer regions are shifted towards higher temperature with respect to those from the remote region, and those from near the inside are shifted even further towards higher temperatures. It appears that all the ORNL data are shifted toward higher temperatures as compared to the data obtained by JAERI. For example, see Fig. 9 which compares the Charpy impact energy for specimens machined from the remote region. In this case, the difference at the 41-J energy level is small, so it is difficult to judge whether this shift is due to scatter or other reasons.

Such a shift toward higher temperature in the ORNL data is also apparent when JAERI and ORNL data from the beltline regions are compared (see Fig. 10). In this case, the JAERI "inside surface" specimens are further away from the inside surface than the ORNL specimens, nearing the radiation dose attenuated for the JAERI specimens. The further shift of the data for the outside surface from both other curves is reasonable, since the dose is even more attenuated than either of the two previous curves.

All the fitted curves are shown on a single plot in Fig. 11. It shows the relationship of all the data together and indicates what was mentioned above, namely, that all of the ORNL data are shifted toward higher temperatures as compared to data from similar regions of the vessel. It is noted that the JAERI specimens were in the T-S orientation while the ORNL specimens were in the T-L orientation. 


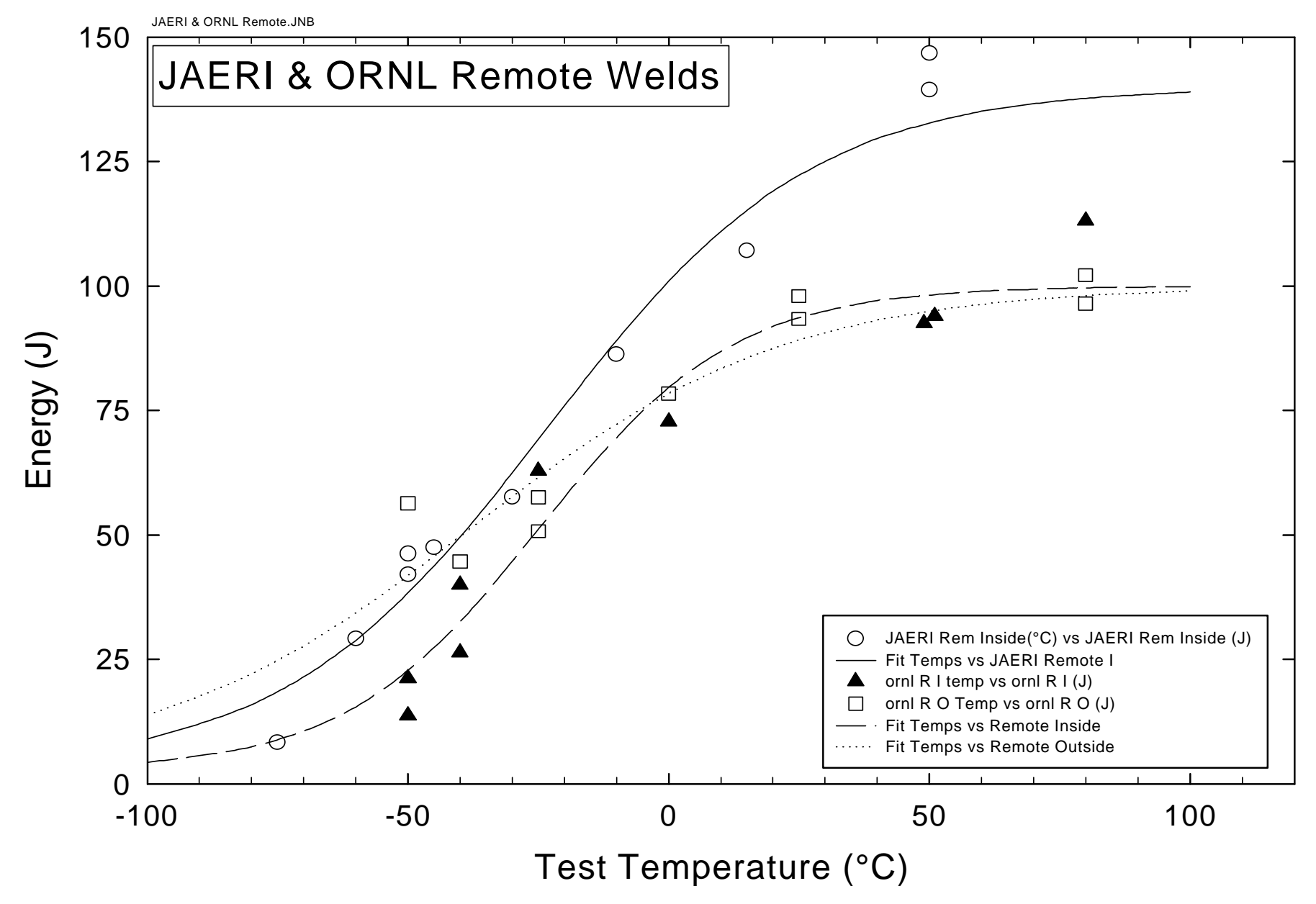

6

Fig. 9. Charpy impact energy versus temperature results for JPDR remote welds, both JAERI and ORNL data. Data are fit to a hyperbolic tangent function. 


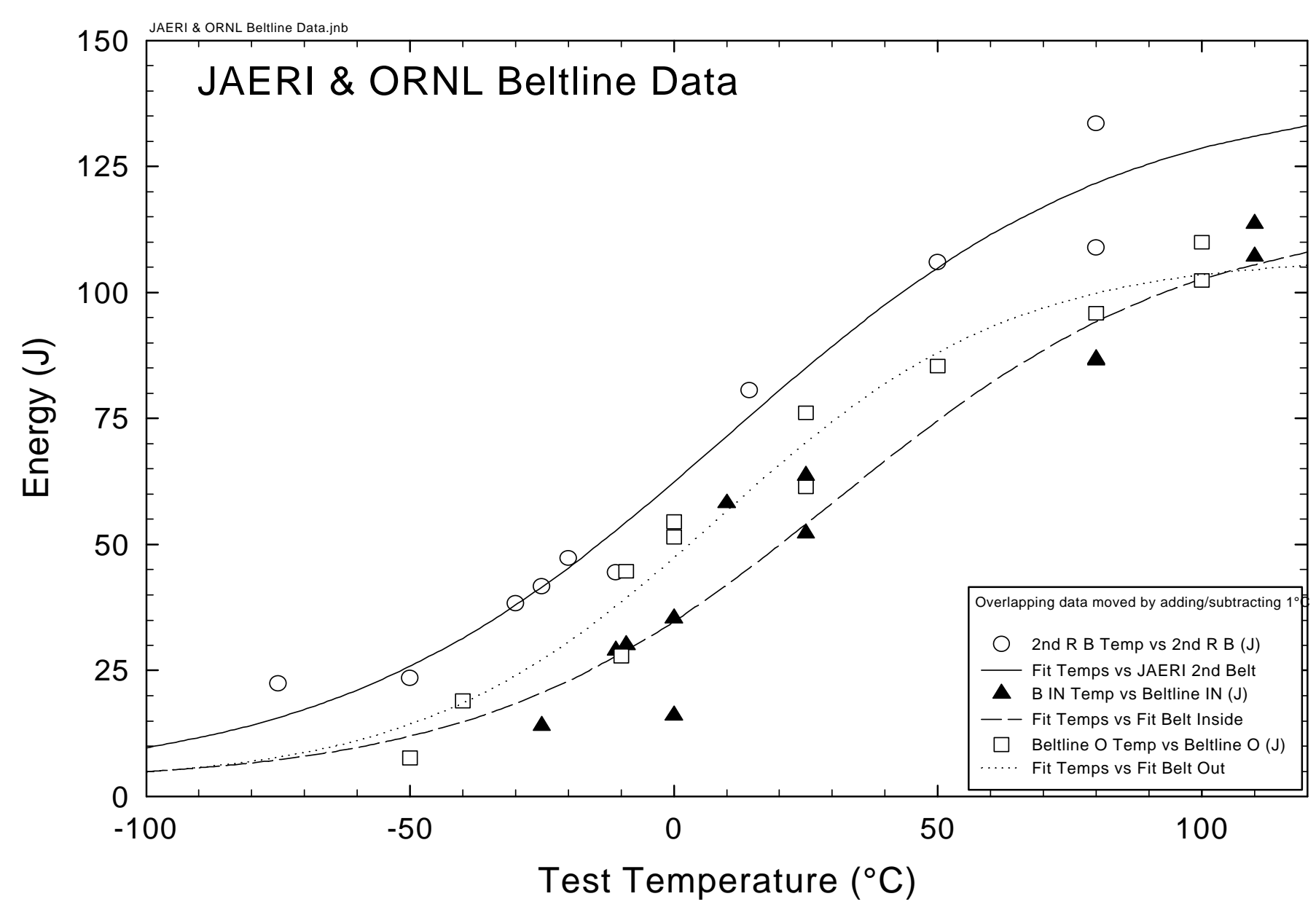

Fig. 10. Charpy impact energy versus temperature results for JPDR beltline welds, both JAERI and ORNL data. Data are fit to a hyperbolic tangent function. 


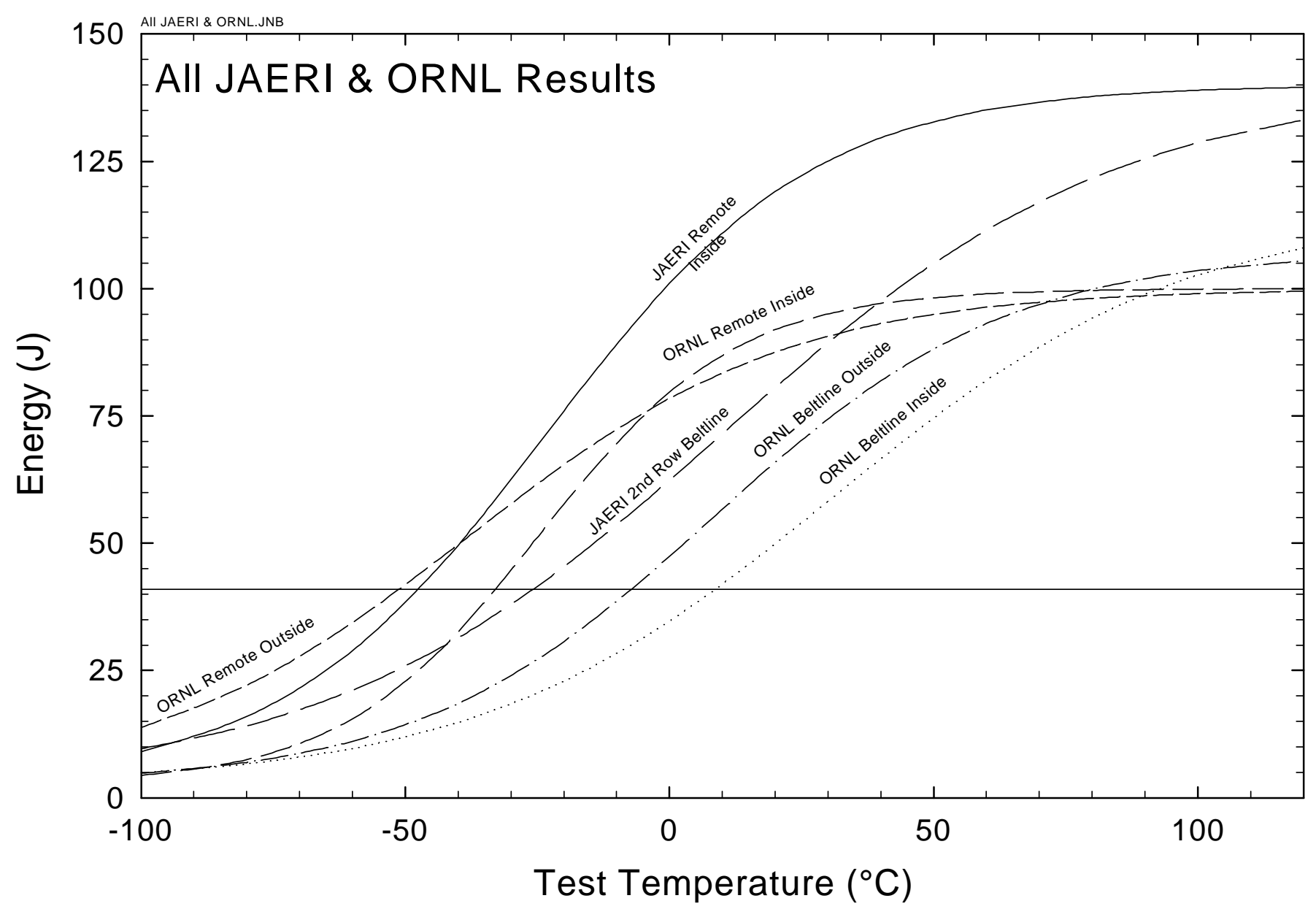

Fig. 11. Charpy impact energy versus temperature mean hyperbolic tangent curves for JPDR remote and beltline welds, both JAERI and ORNL data. 


\section{References}

1. M. Suzuki, Y. Idei, and K. Onizawa, "Investigation on Irradiation Embrittlement of Reactor Pressure Vessel Steel Using Decommissioned JPDR,' in Technology for Lifetime Management of Nuclear Power, Proceedings of a Meeting Organized by the International Atomic Energy Agency, Tokyo, November 15-17, 1994.

2. T. Fujimara, S. Miyazono, S. Ueda, T. Kodaira, K. Shibata, T. Isozaki, T. Oba, R. Kawamura, M. Matsumoto, H. Namatame, and F. Sakamoto, Integrity Assessment for JPDR Pressure Vessel, JAERI-1236 (translated from Japanese), Japan Atomic Energy Research Institute and Mitsubishi Heavy Industries, November 21, 1973.

3. M. Kawasaki, T. Fujimura, K. Suzuki, H. Namatame, and M. Kawasaki, "Evaluation of the Embrittlement of Pressure Vessel Steels Irradiated in JPDR," pp. 74-95 in Irradiation Effects on Structural Alloys for Nuclear Reactor Applications, ASTM STP 484, American Society for Testing and Materials, Philadelphia, 1970.

4. Investigation on Irradiation Embrittlement of JPDR Pressure Vessel Studies - Progress of JAERI Studies, Reactor Component Reliability Laboratory, Japan Atomic Energy Research Institute, March 29, 1995. 
Appendix A

Excerpt from Reference 1 of the Report 


\section{Appendix A}

\section{Excerpt from Reference 1 of the Report}

From the abstract:

Steel pressure vessels of the Japan Power Demonstration Reactor (JPDR) are constructed with stainless steel weld overlay liners on their inner wall. Since the stainless steel overlay cladding is subjected to thermal and internal-pressure loads in reactor operation, it is desirable for the cladding to have higher ductility from the standpoint of structural integrity. In this paper are firstly included several fundamental surveys concerning the mechanical properties and metallographic observations of the overlaid weldment in order to investigate the hair cracks which were detected in the inner surface of its top head in 1966.

This paper also describes the experimental results of three pressure vessel models of JPDR pressure vessel. These model tests were carried out concerning two 1/3 scale mounts of JPDR pressure vessels with two same nozzles and one $1 / 2$ scale model with four different nozzles...

From those results, the following conclusion was drawn; The number of cycles to failure for the JPDR pressure vessel was estimated to be greater than 60,000 .

The following text is also excerpted from the above cited reference from the introduction and gives the reason for the work performed and reported:

...design is a rigid structure design with considerable elastic design interlaced but there can be localized stress discontinuity formed or peak stresses created that are difficult to avoid discontinuous stresses frequently exceed the yield stress and give rise to localized plastic strain. This type of plastic strain becomes subject to low cycle fatigue damage as the result of repeated starts and stops in the reactor operation. When cracks are forced as the result of low cycle fatigue damage, these cracks can propagate and come to limiting crack size, and there is possibility that brittle fracture can set in thereafter depending on the test conditions.

It is generally accepted that the operation and startup of a nuclear power plant will occur about 500 times during the life of the plant. Low cycle fatigue damage usually occurs with very great difficulty at this rate of repeat operations. On the other hands taking into consideration the defects associated with pressure vessels upon which are superimposed multiple axial loads and thermal loads plus the assumption of a life safety factor of 20 , a $10^{4}$ cycle fatigue behavior becomes one of the important problems in fatigue design.

As the first step to the introduction of a light water cooled type nuclear reactor, the Japan Atomic Energy Research Institute brought in a boiling water type 
experimental power reactor from the United States in 1963. The pressure vessel of this reactor, despite the great care that went into its design, developed two problems that threatened its safety after about 10,000 hours of operation. The first item was the large degree of irradiation embrittlement that was discovered during the first inspection test of the pressure vessel steel greatly exceeding the expected degree of radiation embrittlement based on the studies in the design stage indicating low effect of fast neutrons on the life of the pressure vessel. This was the result of the lack of irradiation test data accumulated on the pressure vessel steel for the test power reactor (JPDR), the insufficiency in the computation code with respect to neutron flux distribution, and lack of experience in constructing power reactors all of which did not direct sufficient consideration to radiation embrittlement. As test irradiation data began to accumulate on the research reactor, it became evident that radiation embrittlement is a major problem in the safety evaluation of the pressure vessel of the JPDR. Research on this problem has been completed, and the report on the results of the research has been published thereby establishing a basis for making structural safety evaluations.

The second problem item with respect to the pressure vessel or JPDR resulted from the discovery of the presence of hair cracks in the stainless steel cladding at the inner surface of the pressure vessel.

The formation of fine hair cracks at the stainless steel cladding to the inner surface of the pressure vessel has also been experienced in nuclear reactor components in the United States. The details of the factors responsible for this behavior will be mentioned later, and the selection of the conditions used for the welding to place this cladding is responsible. This formation of hair cracks over the entire surface is one that is almost impossible to avoid. For example, it can be judged that hair cracks are unavoidable at the nozzle sections that are associated with high stress. The aforementioned peak stress is generated at a nozzle section so that the development of the crack is enhanced by the notch effect whenever a hair crack is formed, and it can be thought that fracture life is greatly reduced.

The structural safety problem items discussed above were not only major problems with respect to the safety of continued operation of the JPDR... 


\section{Appendix B}

Sample Photographs of Disks Machined from JPDR Trepans with the Weld Fusion Lines Marked to Indicate Their Locations 


\section{Appendix B}

\section{List of Figures}

Fig. B.1. Disk sawed from beltline trepan 1, as close as possible to inside surface (1F). The shown surface is that closest to the vessel inner surface, i.e., towards the cladding.

Fig. B.2. "Back" surface of same disk as that shown in Fig. B.1. The increase in weld width due to the V-groove weld geometry is apparent.

Fig. B.3. Disk sawed from beltline trepan 2, as close as possible to inside surface (2F). The surface shown is that closest to the vessel inner surface.

Fig. B.4. Back" surface of same disk as that shown in Fig. B.3. The increase in weld width due to the V-groove weld geometry is apparent.

Fig. B.5. Disk sawed from beltline trepan 2, as close as possible to outside surface (2B). The shown surface is that closest to the vessel inner surface. The weld width here is more than double that near the inner surface and shown in Fig. B.3

Fig. B.6. "Back" surface of same disk as that shown in Fig. B.5. The increase in the V-weld thickness is apparent. This is the widest portion of the $\mathrm{V}$-groove weld.

Fig. B.7. Disk sawed from "remote" trepan 9, as close as possible to inside surface (1F). The shown surface is that closest to the vessel inner surface. Note that the edge of the weld closest to the disk center is off center, and no Charpy specimens can be machined in the same orientation as the other specimens.

Fig. B.8. "Back" surface of same disk as that shown in Fig. B.7.

Fig. B.9. Disk from trepan 9 near the outside of the vessel surface; the face shown is that towards the cladding. The weld width is significantly greater than that from the "inner" disks, thus it may be possible to machine one or more Charpy specimens from it if they are needed. 


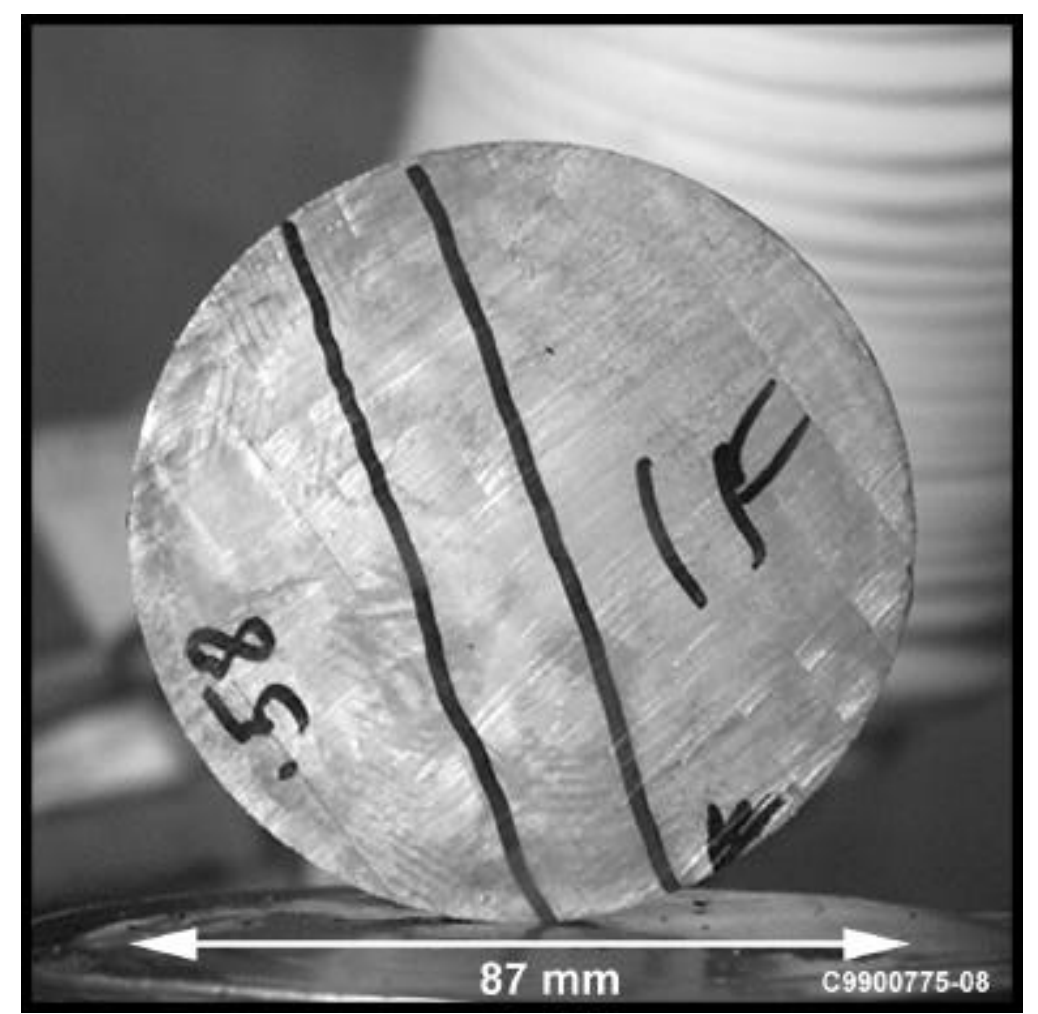

Fig. B.1. Disk sawed from beltline trepan 1, as close as possible to inside surface (1F). The shown surface is that closest to the vessel inner surface, i.e. towards the cladding. 


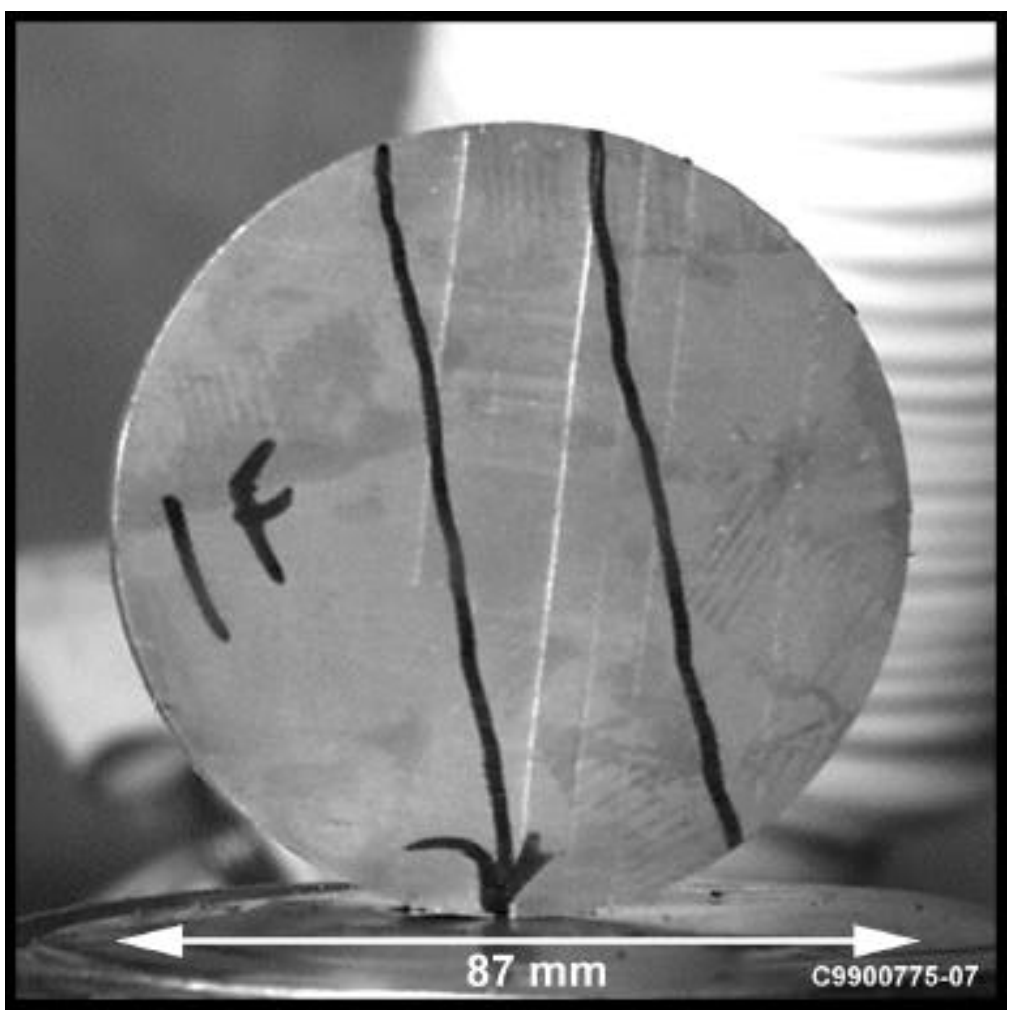

Fig. B.2. "Back" surface of same disk as that shown in Fig. B.1. The increase in weld width due to the V-groove weld geometry is apparent. 


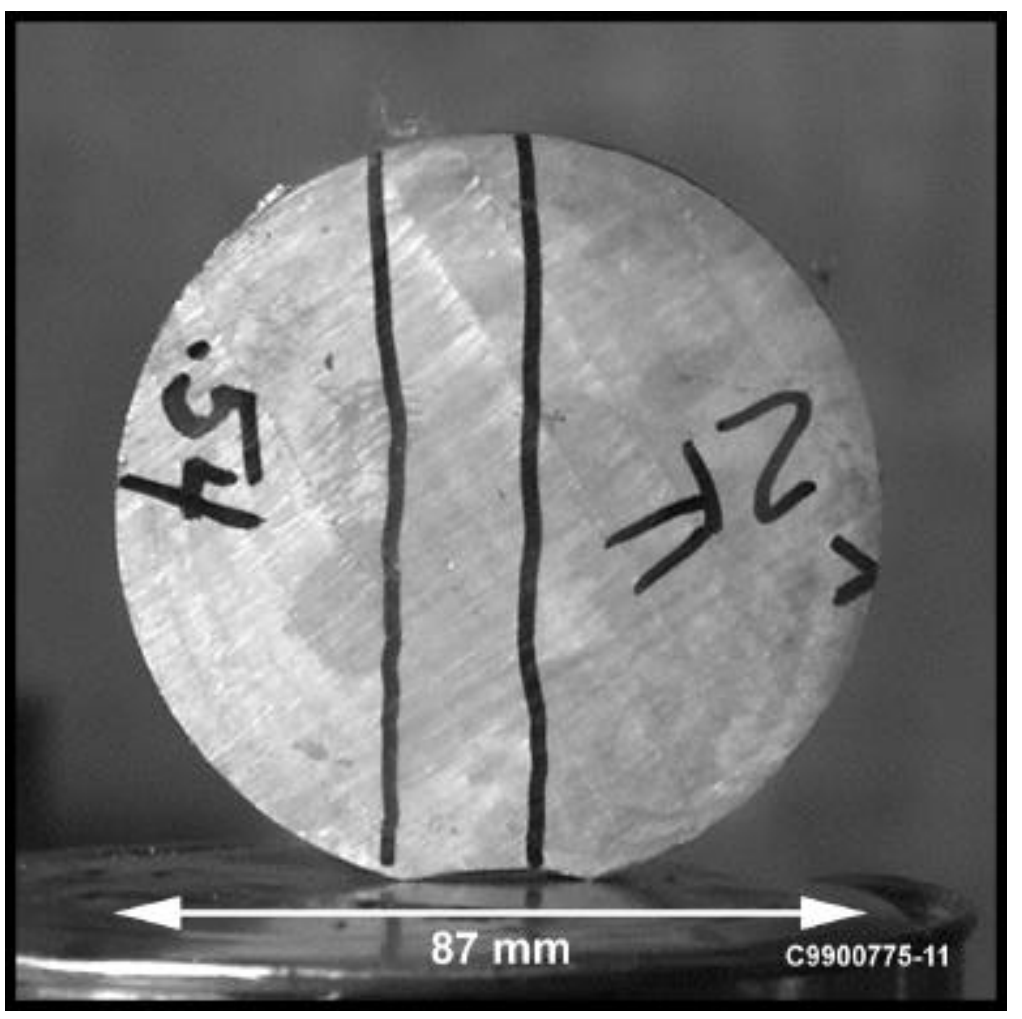

Fig. B.3. Disk sawed from beltline trepan 2, as close as possible to inside surface $(2 \mathrm{~F})$. The surface shown is that closest to the vessel inner surface. 


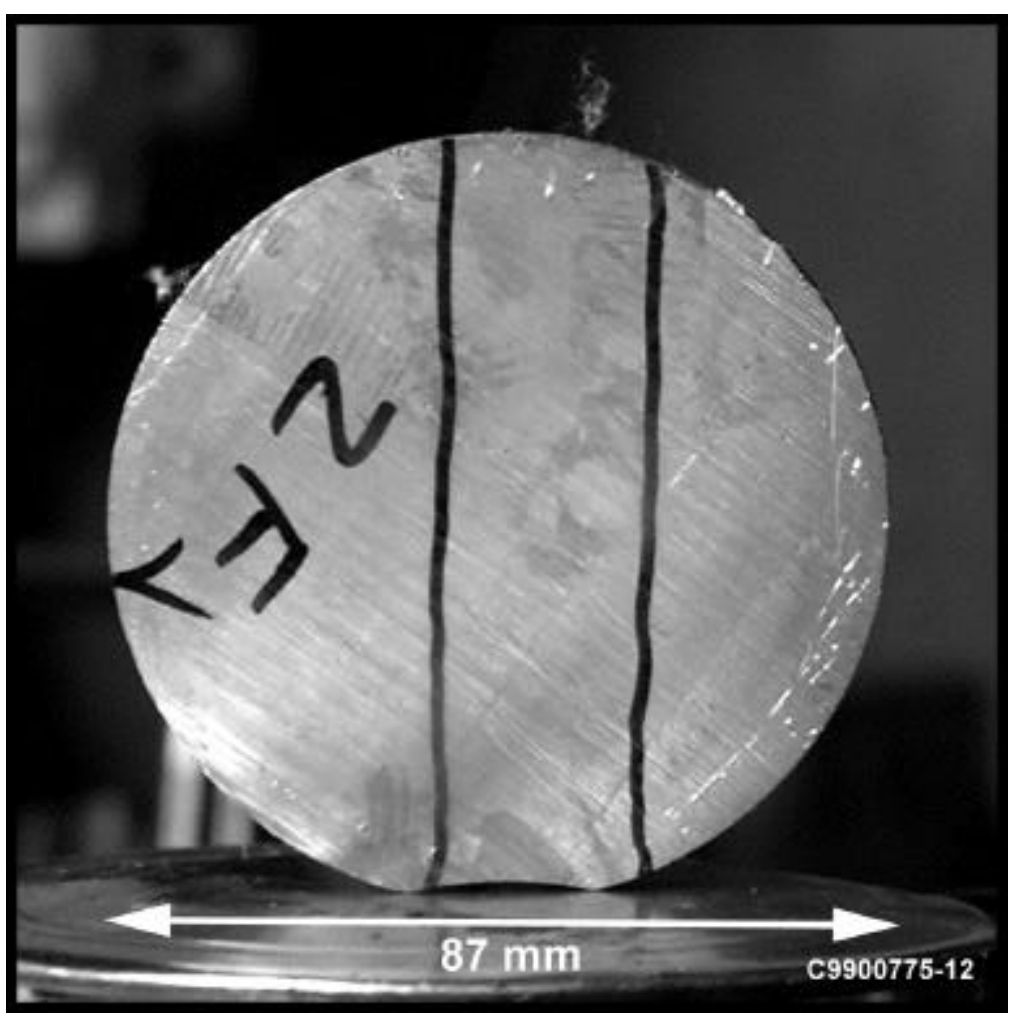

Fig. B.4. Back" surface of same disk as that shown in Fig. B.3. The increase in weld width due to the V-groove weld geometry is apparent. 


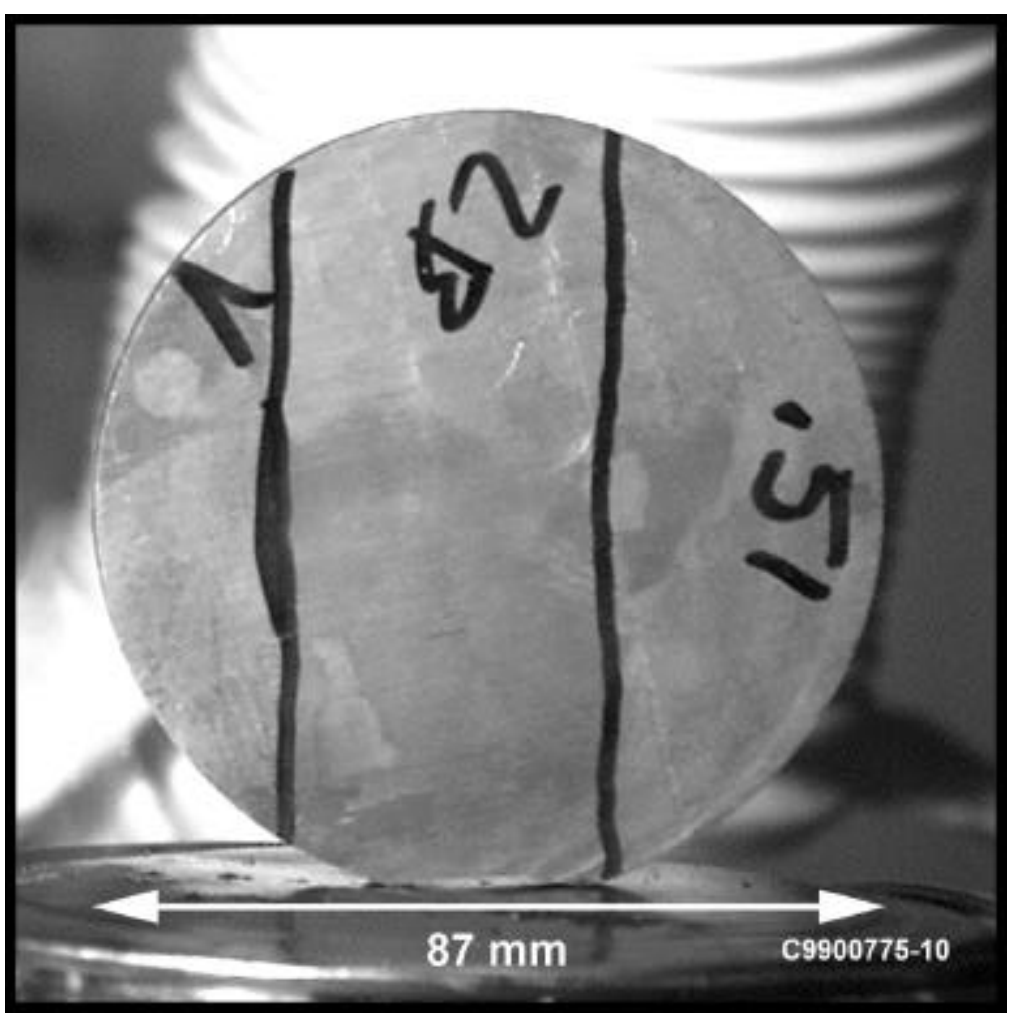

Fig. B.5. Disk sawed from beltline trepan 2, as close as possible to outside surface (2B). The shown surface is that closest to the vessel inner surface. The weld width here is more than double that near the inner surface and shown in Fig. B.3 


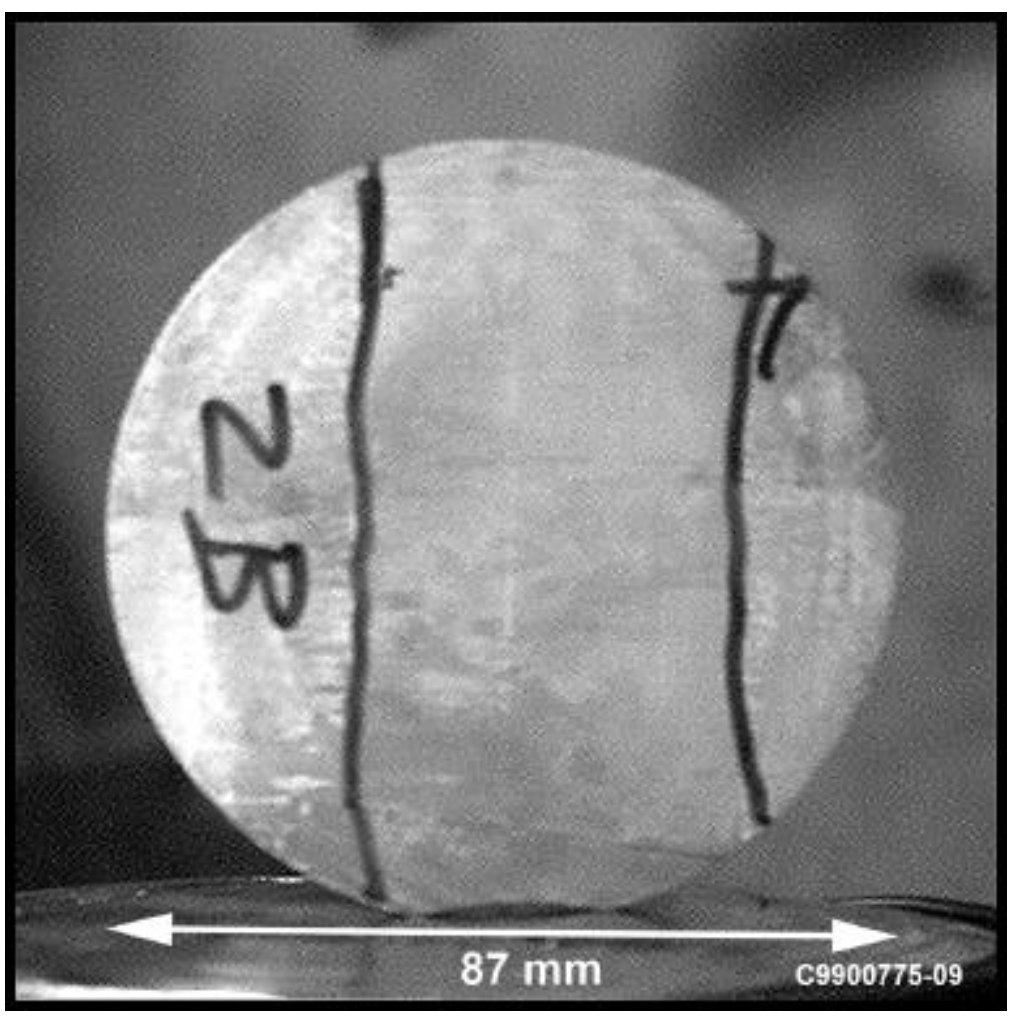

Fig. B.6. "Back" surface of same disk as that shown in Fig. B.5. The increase in the V-weld thickness is apparent. This is the widest portion of the V-groove weld. 


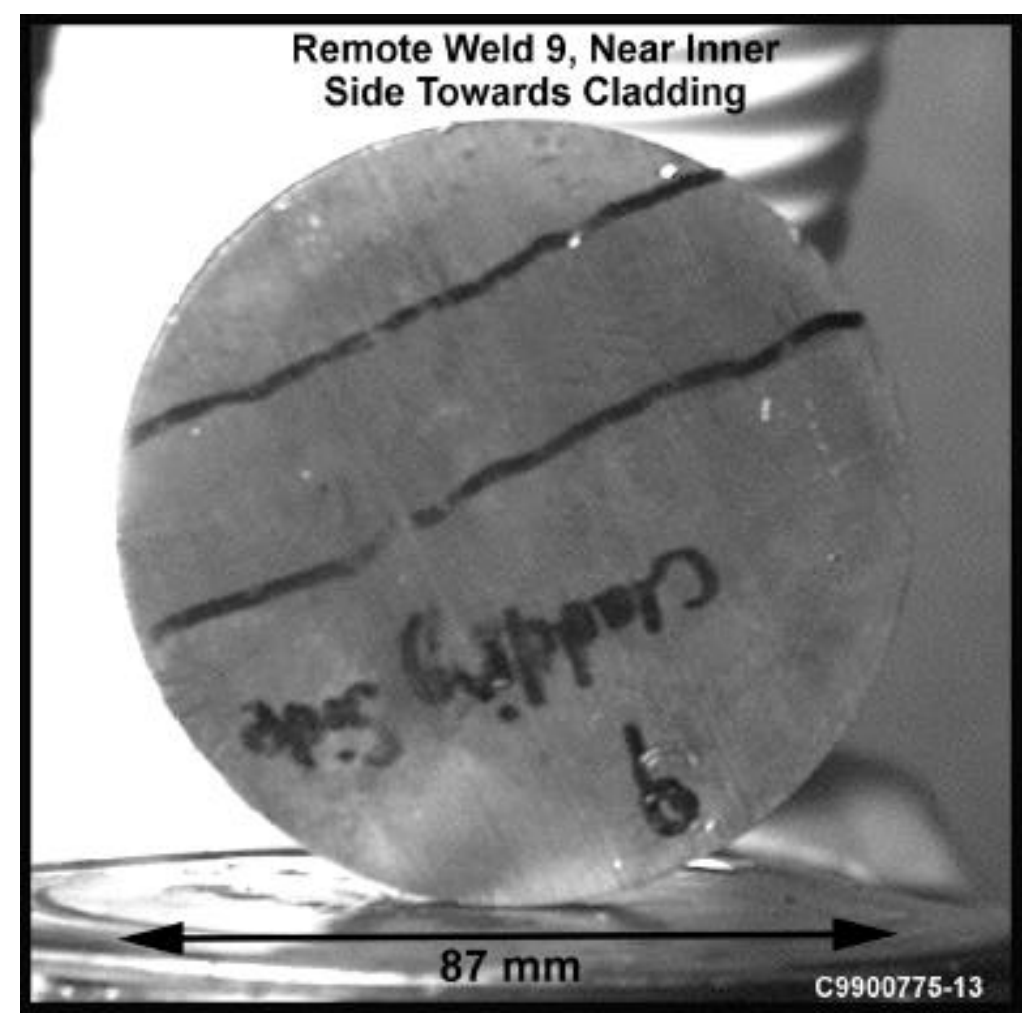

Fig. B.7. Disk sawed from "remote" trepan 9, as close as possible to inside surface (1F). The shown surface is that closest to the vessel inner surface. Note that the edge of the weld closest to the disk center is off center, and no Charpy specimens can be machined in the same orientation as the other specimens. 


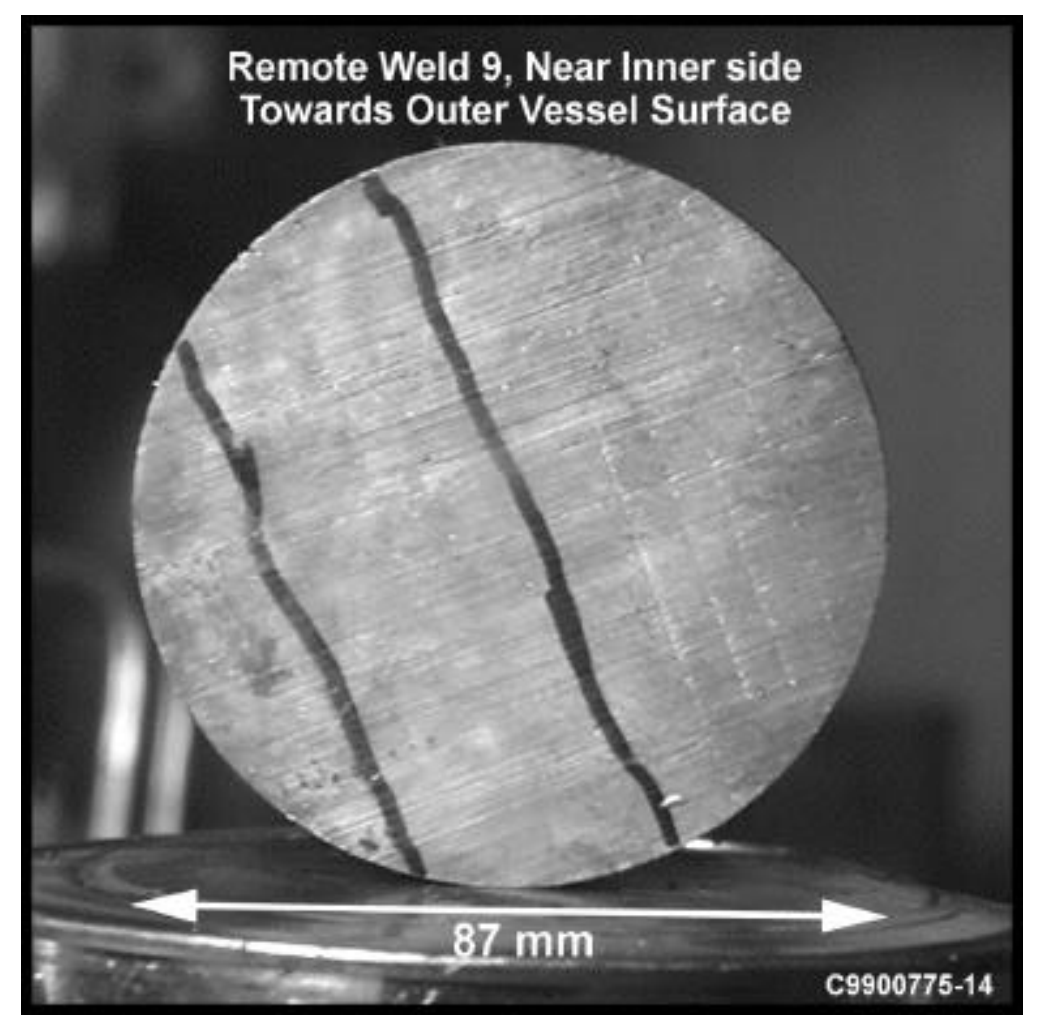

Fig. B.8. "Back" surface of same disk as that shown in Fig. B.7. 


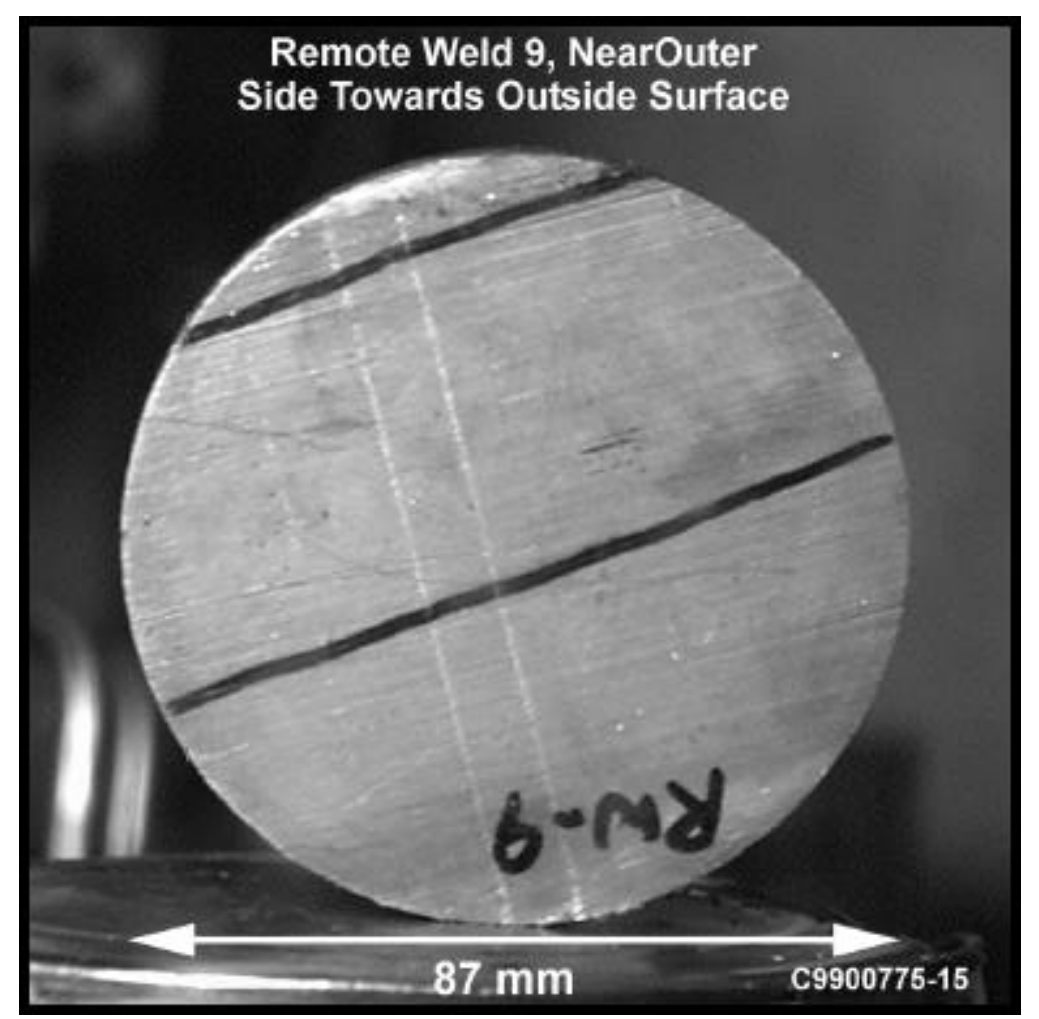

Fig. B.9. Disk from trepan 9 near the outside of the vessel surface; the face shown is that towards the cladding. The weld width is significantly greater than that from the "inner" disks, thus it may be possible to machine one or more Charpy specimens from it if they are needed. 


\section{Appendix C}

Sequence of Operations Required to Machine Charpy Specimens from Irradiated JPDR Trepans 


\section{Appendix C}

\section{Sequence of Operations Required to Machine Charpy Specimens from Irradiated JPDR Trepans}

Photographs where made to document the machining operations on the computer numerically controlled (CNC) mill ("the prototyping mill"), see Fig. C.1. It is used to develop and test the computer programs, in an unirradiated environment, that subsequently control the sequence of operations to machine Charpy specimens. It is anticipated that the machining of the irradiated

Charpy specimens on a nearly identical machine in hot cell would proceed with minimal problems.

1. Two disks mentioned are sawed from each trepan, see Fig. C.2.

2. Each disk is clamped in the first "station" of the fixture. Both surfaces are milled to provide a fresh surface for the etching to reveal the location of the weld, and the fusion line is marked.

3. Machine each face of the disk to provide smooth surfaces to etch. The purpose is to confirm orientation and location of weld in the disk. If the weld is too much off center, the dimensional limitations of the material will not allow positioning of the Charpy notch in the weld. This is particularly important near the inner surface of the vessel, which has suffered the most damage and is of greatest interest. The width of the weld near the inner surface is about $12 \mathrm{~mm}$ wide.

4. The weld location and disk thickness are entered into a computer program The programming is done on an IBM-compatible PC, see Fig. C.1 (left). The program is then downloaded to a control unit, Fig. C.1 (center). The control unit then sends machining commands to the mill, Fig. C.1 (right). The commands position the proper tools over an "X-Y table," prescribes rotational speeds of the tools as well as the feed and depth of cut. The table is capable of moving horizontally, left to right (X-direction), and towards the front or back of the machine (Y-direction). The circular turret, besides holding a bank of a maximum of 9 tools, also moves vertically up or down, (the Z-direction), and also powers the rotational motion of the milling tool after it is positioned over the location to be machined, as seen in Fig. C.3. The fixture also accurately positions the circular disks and/or specimens in various locations that are critical to the accuracy of the machining operations. This is because the disk/specimen are unclamped from one position, and must be accurately positioned in the next position (or station) for machining to continue.

5. After machining the top surface of the disk, four grooves are made that eventually bracket the three Charpy specimens to be machined from a single disk, see Fig. C.3. Three specimens from one disk are assumed to have been exposed to the same flux, hence, together with three other disks from the same location in other trepans will constitute a set of 12 specimens to be tested to produce a single Charpy curve that would describe the damage at this particular depth in the vessel wall. 


\section{C-2}

6. Specimen identifications are engraved on both sides of the specimen. This serves as a means of tracing each specimens to its original location and orientation in the vessel wall relative to the inside surface, as shown in the photo, Fig. C.4. After other grooving operations in a second station, the specimens are parted from the disk, and are ready to have the V-notch machined in the specimen in a third station, as seen in Fig. C.5. 


\section{C-3}

\section{Appendix C}

\section{List of Figures}

Fig. C.1. Guillotine saw installed in hot cell as it cuts one of the JPDR trepans.

Fig. C.2. Prototyping mill installed in the Fracture Mechanics Group Laboratory.

Fig. C.3. Reaming of locating holes on a dummy disk. Machining of four grooves that bracket three Charpy specimen blanks is complete.

Fig. C.4. The three Charpy specimen blanks have been milled to final thickness and parted from the disk.

Fig. C.5. Final operation on Charpy specimen blank: milling of V-groove. 


\section{C-4}

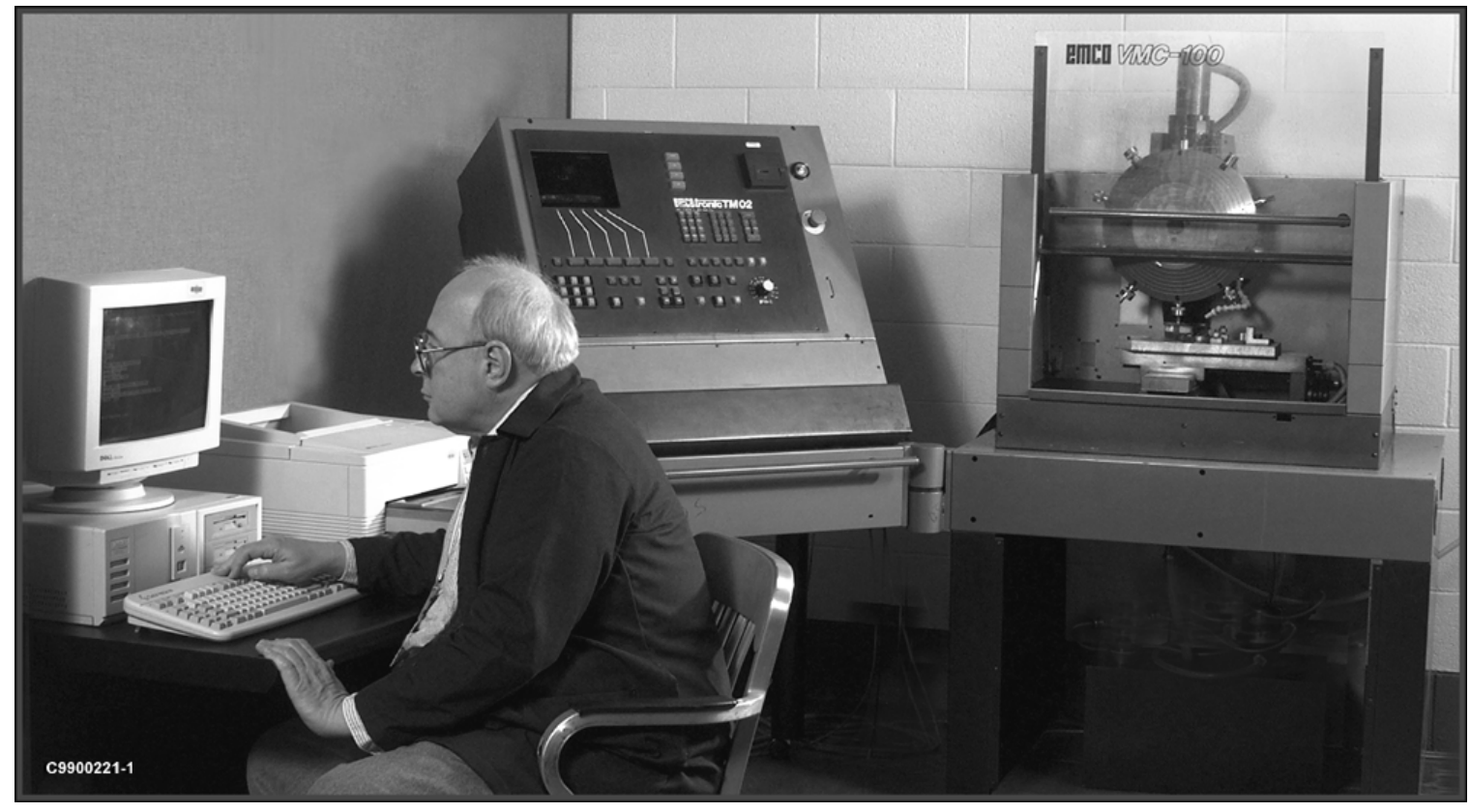

Fig. C.1. Prototyping mill installed in the Fracture Mechanics Group Laboratory. 
C-5

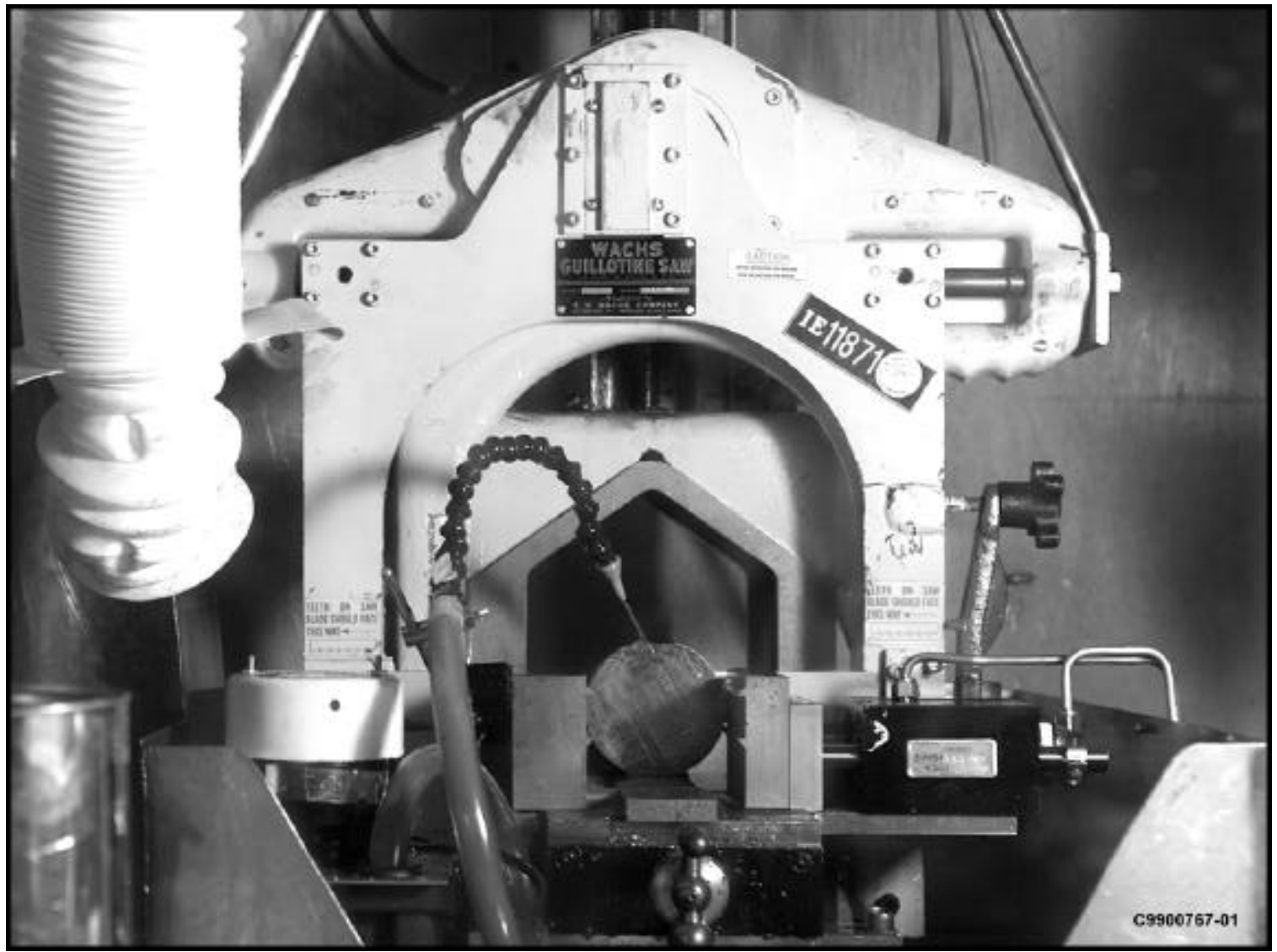

Fig. C.2. Guillotine saw installed in hot cell as it cuts one of the JPDR trepans. 


\section{C-6}

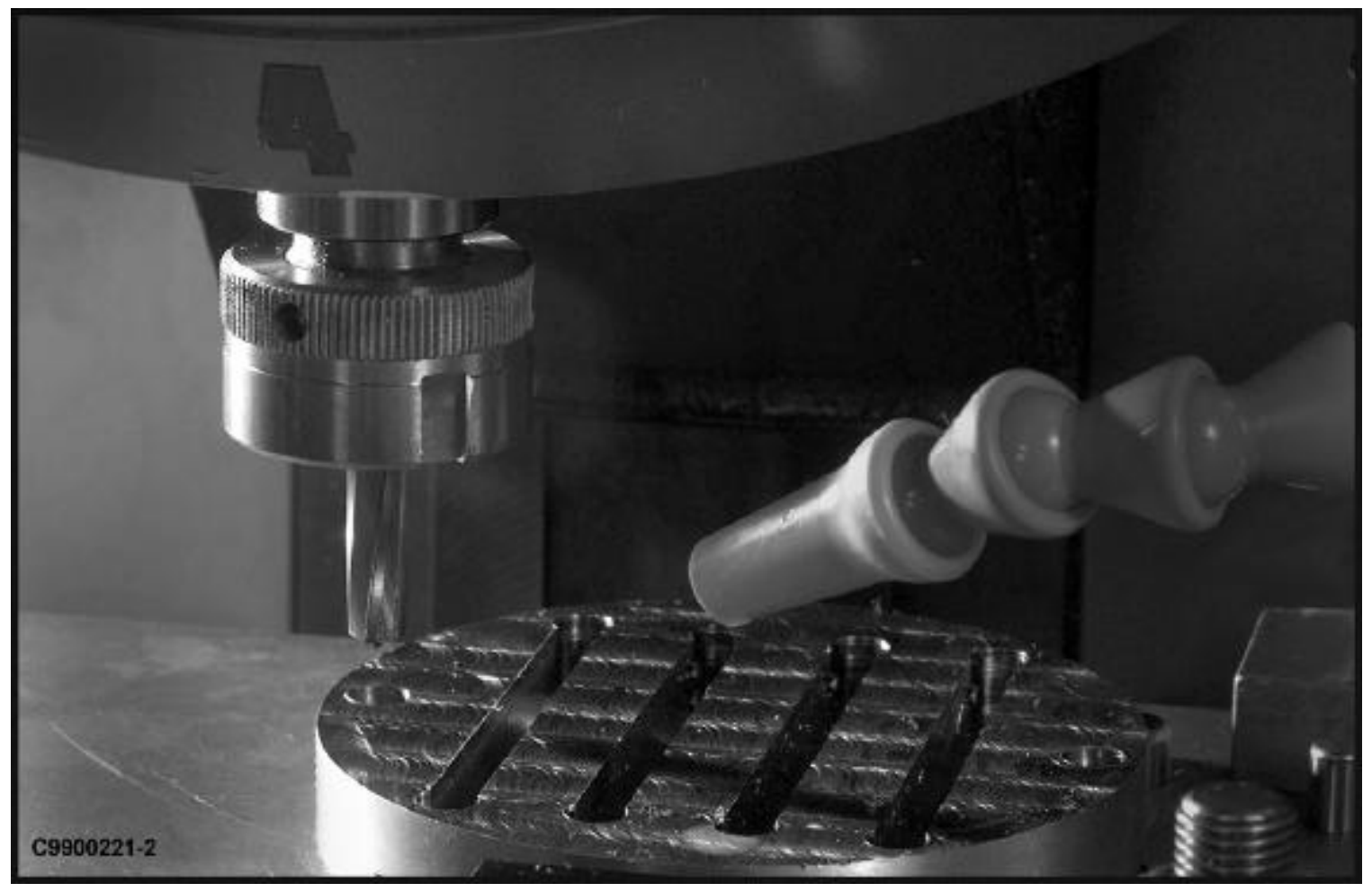

Fig. C.3. Reaming of locating holes on a dummy disk. Machining of four grooves that bracket three Charpy specimen blanks is complete. 


\section{C-7}

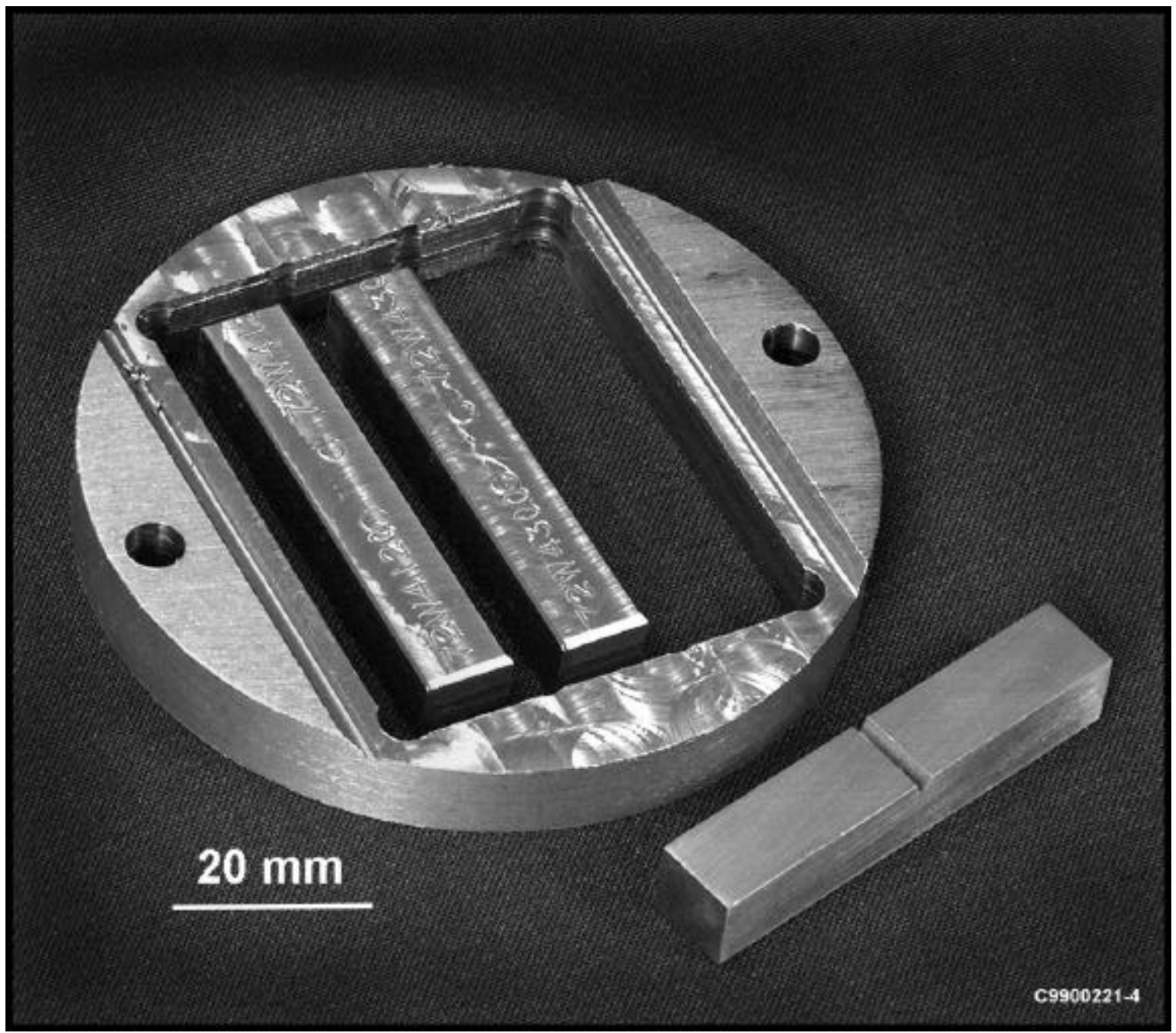

Fig. C.4. The three Charpy specimen blanks have been milled to final thickness and parted from the disk. 


\section{C-8}

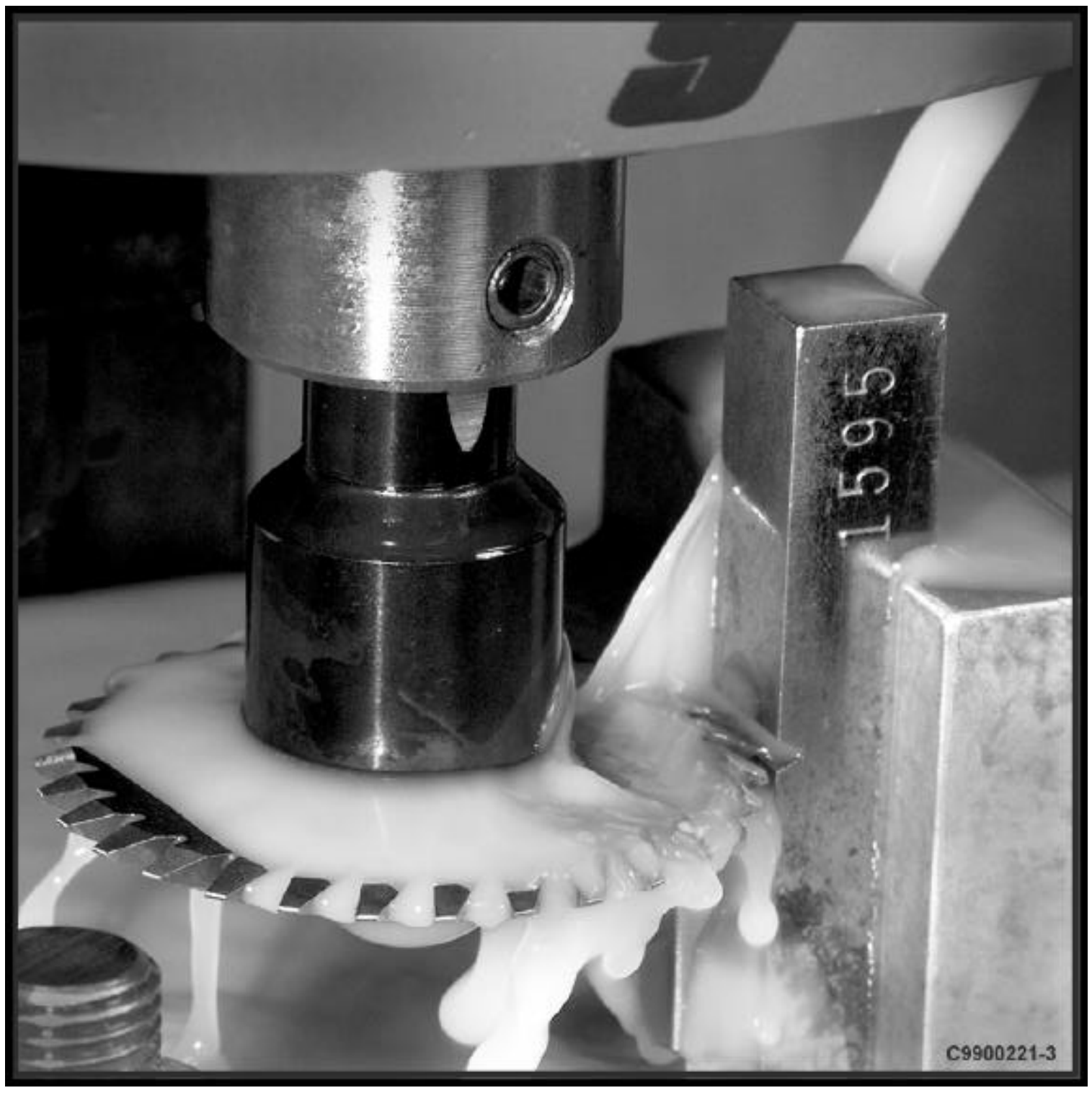

Fig. C.5. Final operation on Charpy specimen blank: milling of V-groove. 


\section{Internal Distribution}

1. B. R. Bass

2. P. S. Bishop

3. E. E. Bloom

4-5. L. E. Creech

6. R. G. Gilliland

7. L. L. Horton

8-9. J. T. Hutton

10-14. S. K. Iskander

15. E. T. Manneschmidt

16. D. E. McCabe

17. G. E. Michaels
18. D. L. Moses
19-20. R. K. Nanstad
21. D. J. Naus
22. C. E. Pugh
23. J. B. Roberto
24-28. T. M. Rosseel
29. A. F. Rowcliffe
30. M. A. Sokolov
31. R. E. Stoller
32. R. L. Swain
33. L. J. Turner

\section{External Distribution}

34. E. M. Hackett, RES/DET/MEB, U.S. Nuclear Regulatory Commission, Washington, DC 20555-0001

35. C. J. Fairbanks, RES/DET/MEB, U.S. Nuclear Regulatory Commission, Washington, DC 20555-0001

36. J. D. Lee, OCM/SAJ, U.S. Nuclear Regulatory Commission, Washington, DC 20555-0001

37. A. C. Thadani, Director, Office of Nuclear Regulatory Research, U.S. Nuclear Regulatory Commission, Washington, DC 20555-0001

38. M. V. Federline, Deputy Director, RES/OD, U.S. Nuclear Regulatory Commission, Washington, DC 20555-0001

39. M. E. Mayfield, Director, RES/DET, U.S. Nuclear Regulatory Commission, Washington, DC 20555-0001

40. Shah Malik, RES/DET/MEB, U.S. Nuclear Regulatory Commission, Washington, DC 20555-0001

41. M. T. Kirk, RES/DET/MEB, U.S. Nuclear Regulatory Commission, Washington, DC 20555-0001

42. A. Szukiewicz, RES/FMPAS, U.S. Nuclear Regulatory Commission, Washington, DC 20555-0001

43. D. Harrison, U.S. Department of Enrgy, NE-20, 19901 Germantown Road, Germantown, MD 20874-1290

44. P. L. Gorman, ORNL Site Manager Office, Oak Ridge, TN 37831-6269

45. OSTI, Attn: D. Bellis, P.O. Box 62, Oak Ridge, TN 37830

46. S. T. Rosinski, Electric Power Research Institute, 1300 Harris Boulevard, Charlotte, NC 28262

47. J. Lange, Electric Power Research Institute, 1300 Harris Boulevard, Charlotte, NC 28262

48. J. Lance, Electric Power Research Institute, 1300 Harris Boulevard, Charlotte, NC 28262 